\title{
Apparent Benzene Solubility in Tetraphenylborate Slurries
}

by

R. F. Swingle

Westinghouse Savannah River Company

Savannah River Site

Aiken, South Carolina 29808

R. A. Peterson

C. L. Crawtord

\section{RECEIVED \\ JAN 151998 \\ OSTI}

HH

This paper was prepared in connection with work done under the above contract number with the U.S. Department of Energy. By acceptance of this paper, the publisher and/or recipient acknowledges the U.S. Government's right to retain a nonexclusive, royalty-free license in and to any copyright covering this paper, along with the right to reproduce and to authorize others to reproduce all or part of the copyrighted paper. 


\section{DISCLAIMER}

This report was prepared as an account of work sponsored by an agency of the United States Government. Neither the United States Government nor any agency thereof, nor any of their employees, makes any warranty, express or implied, or assumes any legal liability or responsibility for the accuracy, completeness, or usefulness of any information, apparatus, product, or process disclosed, or represents that its use would not infringe privately owned rights. Reference herein to any specific commercial product, process, or service by trade name, trademark, manufacturer, or otherwise does not necessarily constitute or imply its endorsement, recommendation, or favoring by the United States Government or any agency thereof. The views and opinions of authors expressed herein do not necessarily state or reflect those of the United States Government or any agency thereof.

This report has been reproduced directly from the best available copy.

Available to DOE and DOE contractors from the Office of Scientific and Technical Information, P. O. Box 62, Oak Ridge, TN 37831; prices available from (423) 576-8401.

Available to the public from the National Technical Information Service, U. S. Department of Commerce, 5285 Port Royal Road, Springfield, VA 22161. 


\section{DISCLAIMER}

Portions of this document may be illegible electronic image products. Images are produced from the best available original document. 
Keywords: Benzene

Solubility

Tetraphenylborate

In-Tank Precipitation

Retention Time: Permanent

\section{Apparent Benzene Solubility in Tetraphenylborate Slurries (U)}

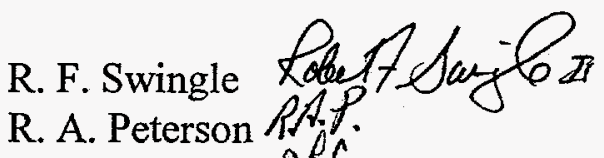

C. L. Crawford CR

Publication Date: November, 1997

Westinghouse Savannah River Company

Savannah River Technology Center

Aiken, SC 29808

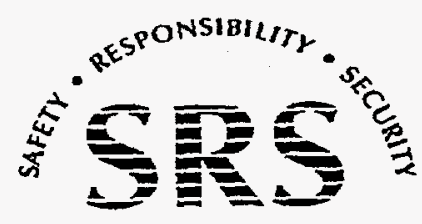




\section{SUMMARY}

Personnel conducted testing to determine the apparent solubility of benzene in potassium tetraphenylborate (KTPB) slurries. The lack of benzene vapor pressure suppression in these tests indicate that for a $6.5 \mathrm{wt} \%$ solids KTPB slurry in $4.65 \mathrm{M} \mathrm{Na}^{+}$salt solution at approximately $25^{\circ} \mathrm{C}$, no significant difference exists between the solubility of benzene in the slurry and the solubility of benzene in salt solution without KTPB solids. The work showed similar results in slurry with $6,000 \mathrm{mg} / \mathrm{L}$ sludge and $2,000 \mathrm{mg} / \mathrm{L}$ monosodium titanate added. Slurries containing tetraphenylborate decomposition intermediates (i.e., $4,200 \mathrm{mg} / \mathrm{L}$ triphenylboron (3PB), $510 \mathrm{mg} / \mathrm{L}$ diphenylborinic acid (2PB) and $1,500 \mathrm{mg} / \mathrm{L}$ phenylboric acid (1PB)) or $100 \mathrm{mg} / \mathrm{L}$ tri-n-butyl phosphate (TBP) also showed no significant difference in benzene solubility from filtrate containing no KTPB solids. Slurry containing $2,000 \mathrm{mg} / \mathrm{L}$ Surfynol ${ }^{T M} 420$ did exhibit significant additional benzene solubility, as did irradiated slurries. The vapor pressure depression in the irradiated slurries presumably results from dissolution of biphenyl and other tetraphenylborate irradiation products in the benzene.

\section{INTRODUCTION}

During operation of the In-Tank Precipitation (ITP) facility, benzene is formed as a result of the decomposition of sodium tetraphenylborate (NaTPB). ${ }^{1}$ The benzene released during tank stirring is retained by the tetraphenylborate (TPB) solids in the tank during quiescent, unstirred periods. An understanding of retention of the benzene by solids in the tank is important to understanding and predicting releases from the tank. Generation and release calculations use benzene vapor-equilibrium (Henry's Law) constants as key parameters. ${ }^{2}$ Walker reported vapor-liquid equilibrium information for benzene in simulated ITP salt solutions. ${ }^{3}$ However, until recently, no work determined the amount of benzene held by TPB slurries. Crawford began work to determine the benzene capacity of the slurry. Crawford's work indicated that slurries could hold more benzene than salt solution. High Level Waste Engineering (HLWE) requested further information about the benzene capacity of the slurries to resolve questions on TPB slurry benzene retention and release as described in the Defense Nuclear Facility Safety Board (DNFSB) Recommendation 96-1 Implementation Plan, ${ }^{5,6}$ This report documents the results of tests to determine the apparent solubility of benzene in KTPB slurries. ${ }^{7,8,9}$

\section{DISCUSSION}

\section{Crawford's Tests}

During 1996, Crawford conducted several tests which indicated that the solubility of benzene in KTPB slurries containing $\geq 3 \mathrm{wt} \%$ solids was increased over that of filtrate containing no solids or $\leq 1 \mathrm{wt} \%$ solids. ${ }^{4}$ The apparent solubility of $3 \mathrm{wt} \% \mathrm{KTPB}$ slurry at $35^{\circ} \mathrm{C}$ was estimated to be $\sim 1800 \mathrm{mg} / \mathrm{L}$ as opposed to $\sim 200 \mathrm{mg} / \mathrm{L}$ for filtrate or slurry containing $\leq 1 \mathrm{wt} \% \mathrm{KTPB}$ solids. This apparent solubility of benzene in slurry is defined as the lowest benzene concentration in the slurry that produced a saturated vapor phase. The suppression of vapor pressure was thought to result from adsorption of benzene in the slurry onto the solids, increasing the benzene capacity for the slurry above that which would be dissolved in the filtrate. Crawford's method used a magnetic stirrer to agitate slurries kept in a constant temperature in a water bath. Figure 1 gives a diagram of Crawford's Vessel. Data from Crawford's tests are given in Figures $2\left(25^{\circ} \mathrm{C}\right)$ and $3\left(35^{\circ} \mathrm{C}\right)$. The results at both temperatures indicate that for slurries containing $\leq 1 \mathrm{wt} \%$ solids, there is no apparent solubility effects. For slurries containing $\geq 3 \mathrm{wt} \%$ solids, an apparent solubility effect is evident. Tests with benzene dyed red to enhance the visibility indicated that this method did not consistently give good mixing and therefore contact between slurry phase and the vapor phase might not be adequate to obtain equilibrium within a reasonable time. Task technical and QA plans were issued to further study this effect. ${ }^{7,8}$ Because Crawford's work and a variety of previous work conducted by SRTC personnel indicated that benzene was difficult to completely contain, an initial method was developed to examine the benzene solubility in KTPB slurries by measuring both the slurry and vapor phase benzene concentrations. ${ }^{?}$ 
WSRC-TR-97-00362

Revision 0

Page 3 of 24

November 13, 1997

Figure 1. Crawford Test Method Vessel

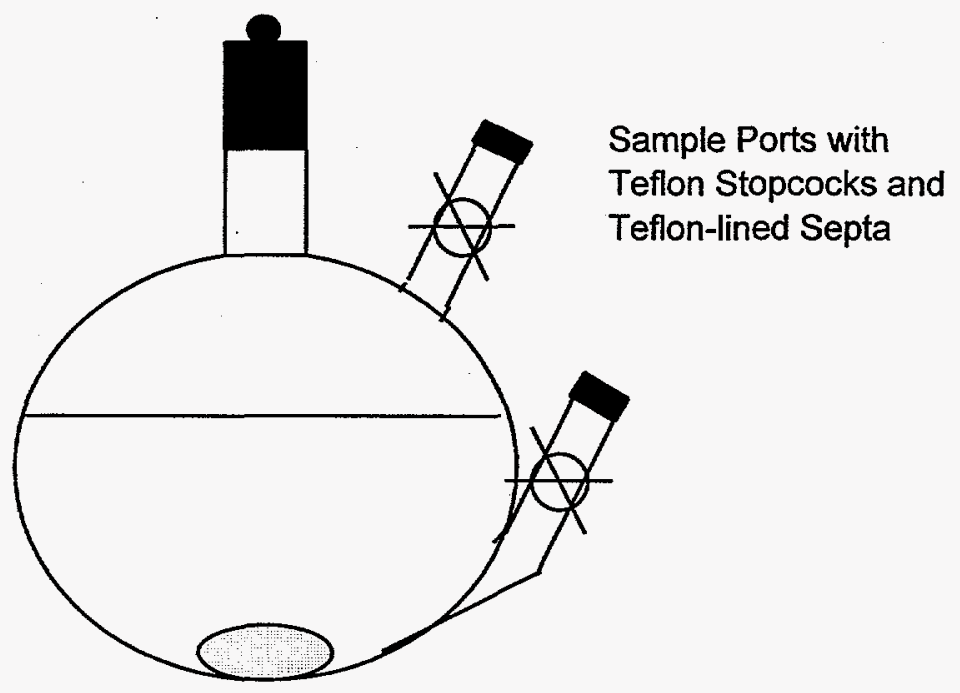

Magnetic Stir Bar

Figure 2. Results of Crawford's Tests at $25^{\circ} \mathrm{C}$

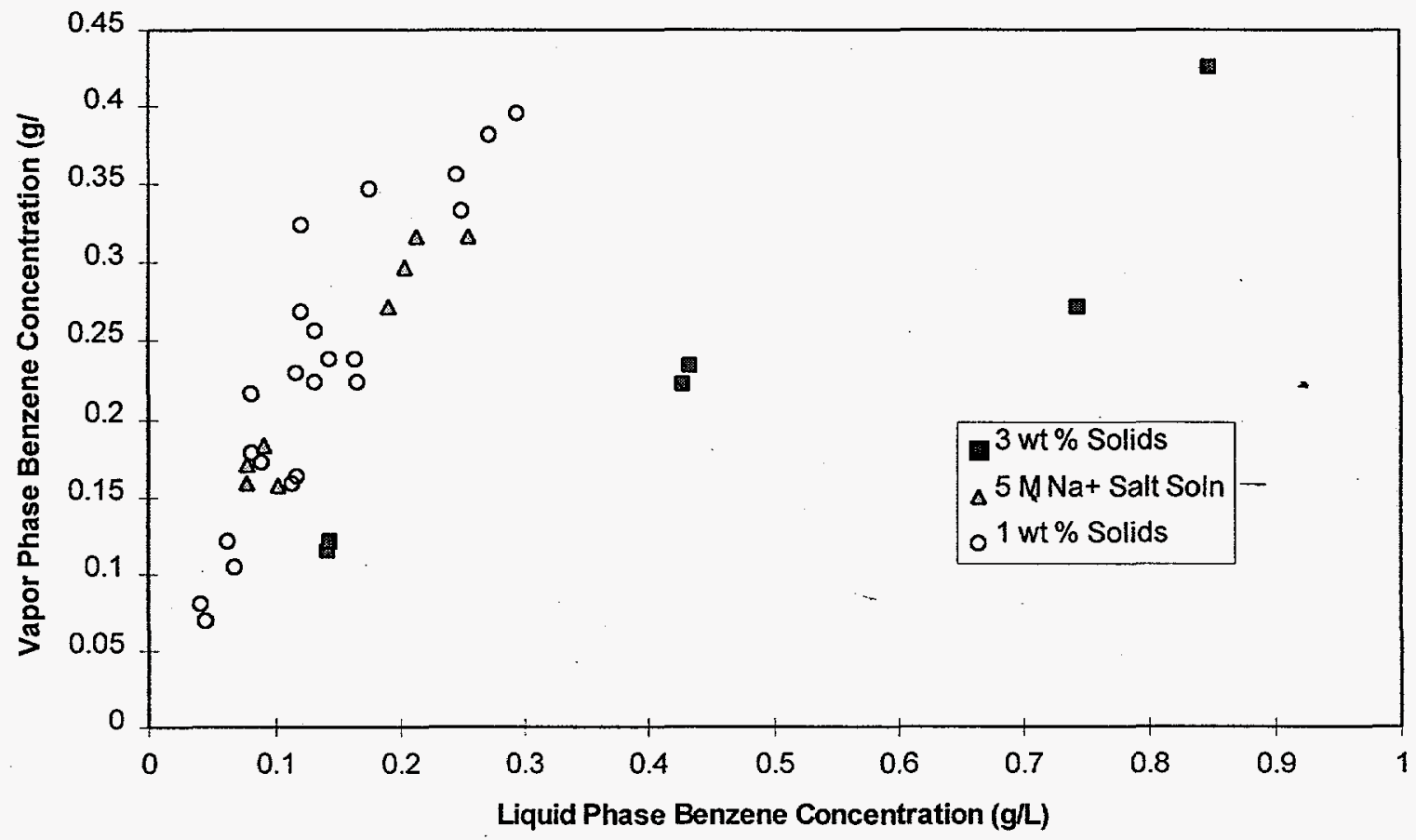


Page 4 of 24

November 13, 1997

Figure 3. Results of Crawford's Tests at $35^{\circ} \mathrm{C}$

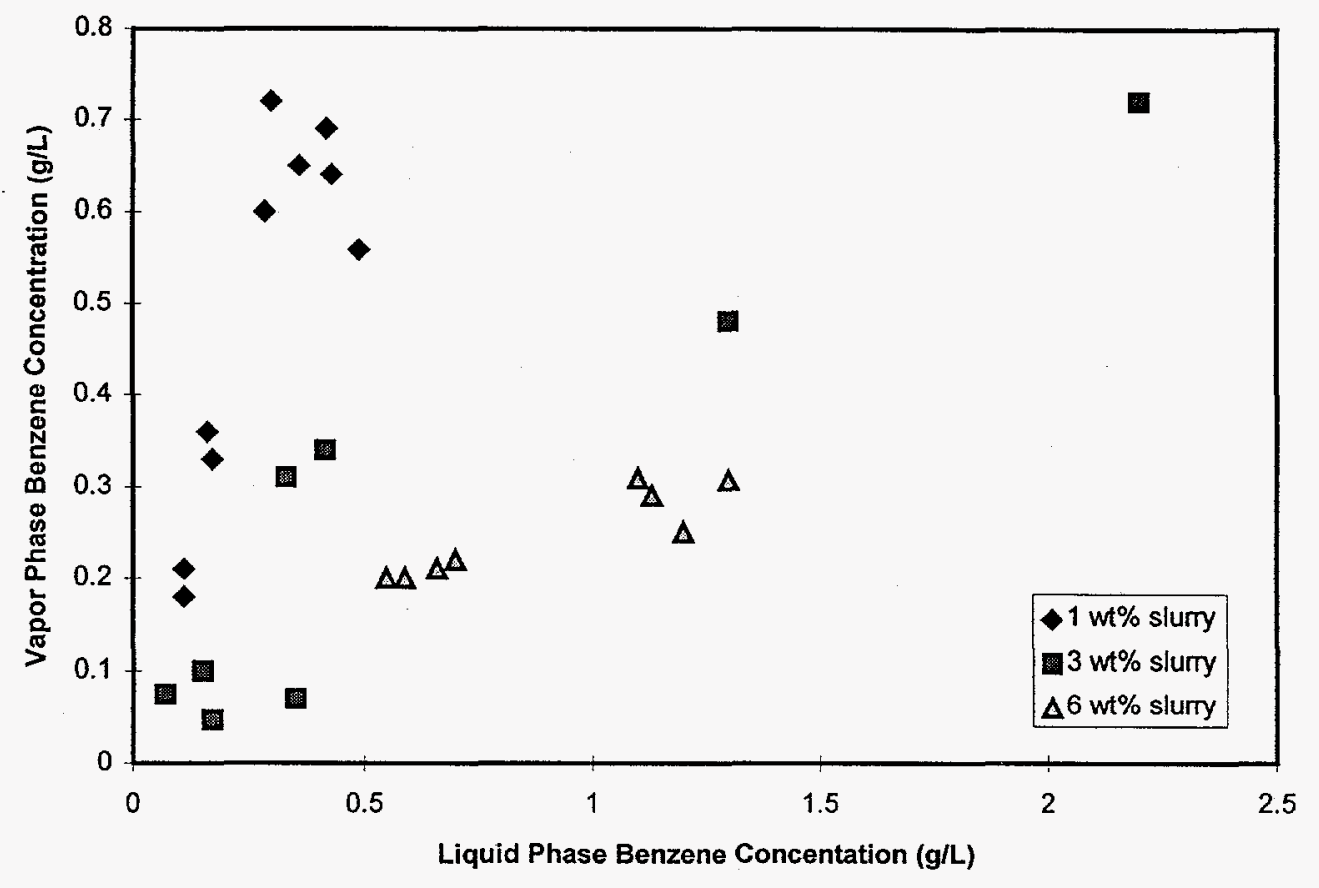

\section{$\underline{\text { Initial Test Method }}$}

Researchers prepared KTPB slurries. An aliquot of slurry was placed in each test vessel and the vessel closed. Figure 4 is a diagram of the initial test method vessel. An amount of benzene specified by the researcher was injected into the slurry through a septum. The test vessel was placed in a temperature controlled shaker/water bath. The slurry was allowed to agitate until vapor and liquid concentrations stabilize. The vessels were checked visually to verify effectiveness of agitation. The test vessels were vented periodically during the first few hours of equilibration to avoid pressurization of the test vessel. After allowing the vapor and liquid to equilibrate, samples were drawn from both slurry and vapor phases and analyzed for benzene using gas chromatography. Tests of this method using dyed benzene indicated satisfactory mixing.

Figure 4. Initial Test Method Vessel

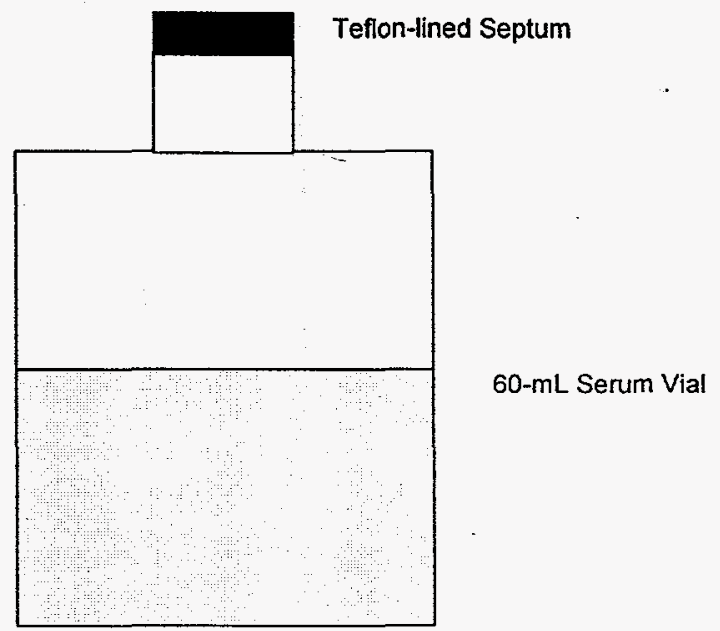


Page 5 of 24

November 13, 1997

Tests of this method seemed to indicate no apparent solubility effect in the slurries tested. The difference between these results and previous results from Crawford was attributed to a lack of adequate mixing in the Crawford tests. However, the slurry phase benzene concentration results proved erratic and therefore cast doubts on the interpretation of the results. Figure 5 gives an example of the results using this method for a 6.5 wt \% solids slurry containing $5 \mathrm{M} \mathrm{Na}^{+}$at $35^{\circ} \mathrm{C}$.

Figure 5. Example of Slurry and Vapor Phase Benzene Concentrations Using Initial Test Method

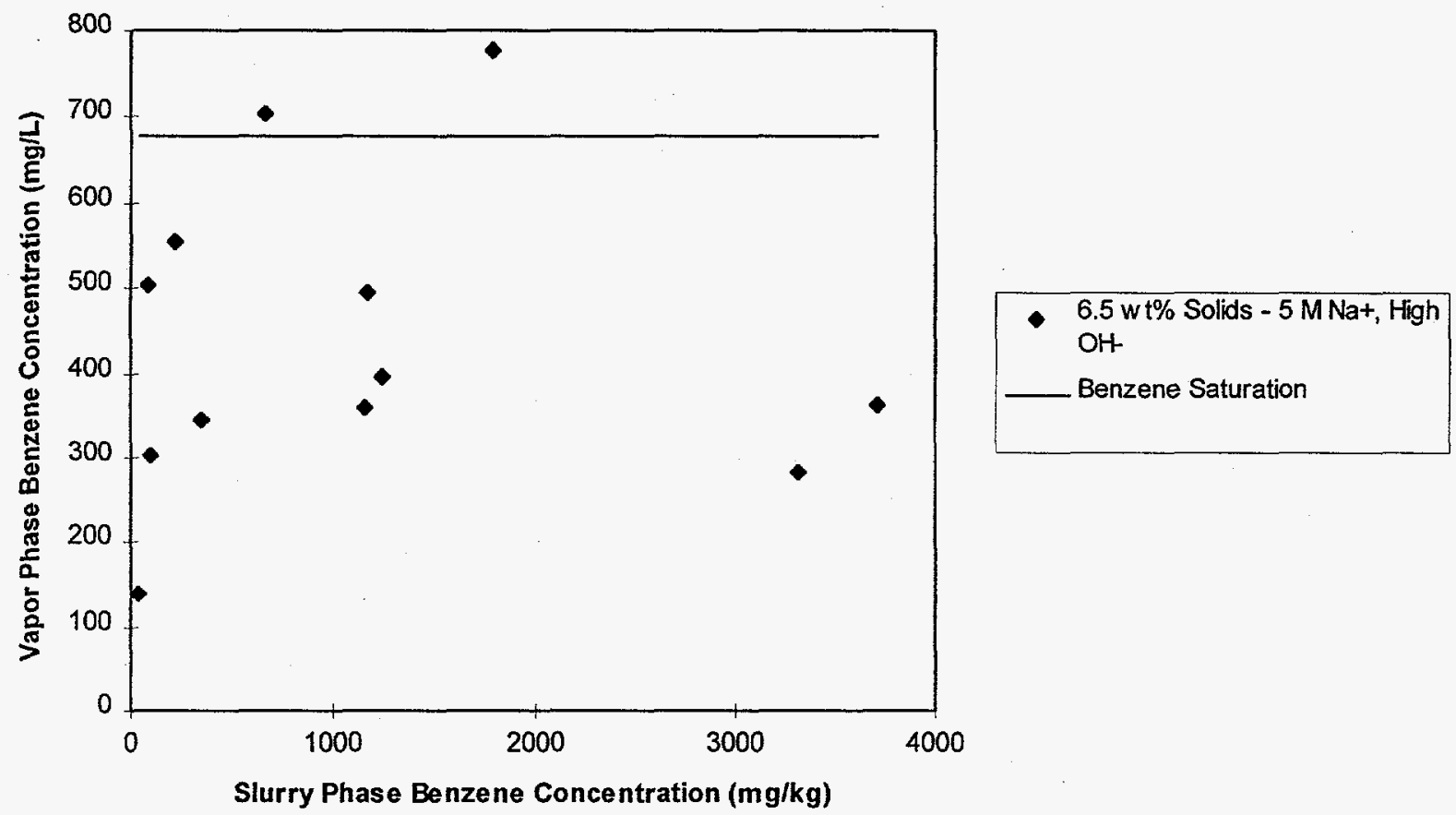

\section{Second Test Method}

The authors decided to reconsider use of a mass balance method. In this method a known amount of benzene is injected into a sealed test vessel containing slurry. Figure 6 contains a diagram of the vessel. The vessel was agitated in the shaker water bath overnight. A sample of the vapor phase was taken and analyzed for benzene using gas chromatography, and the slurry phase benzene calculated by subtracting the benzene in the vapor phase from the total benzene added. ${ }^{9}$ 
Figure 6. Second Test Vessel

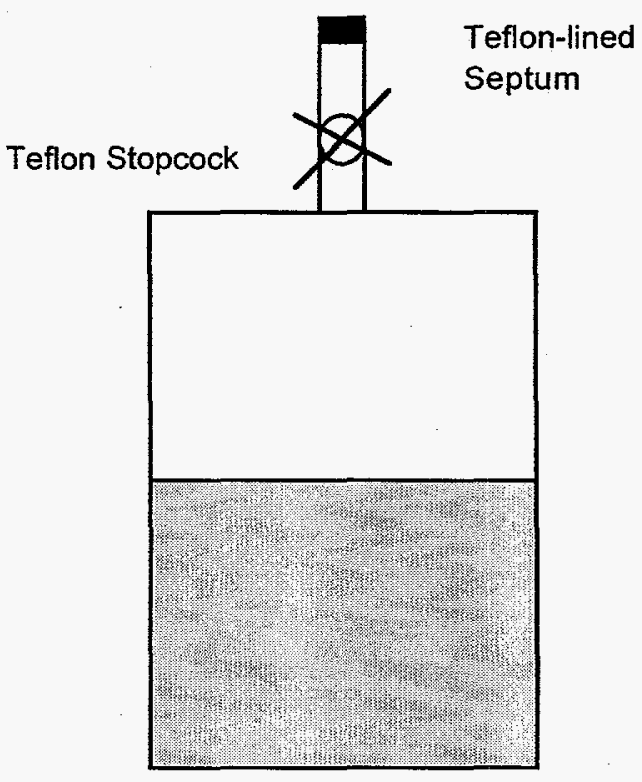

Preliminary tests of this method with vapor phase benzene indicated good, but incomplete containment of the benzene ( $80-100 \%$ found) and insignificant benzene losses over time (Figures 7 and 8 ). Preliminary tests with benzene in water gave good agreement with referenced data for water (Figure 9), and the data improved when calculated liquid phase benzene concentrations were used instead of measured (Figure 10) as done for the slurry tests.

Figure 7. Vapor Phase Benzene Test Results

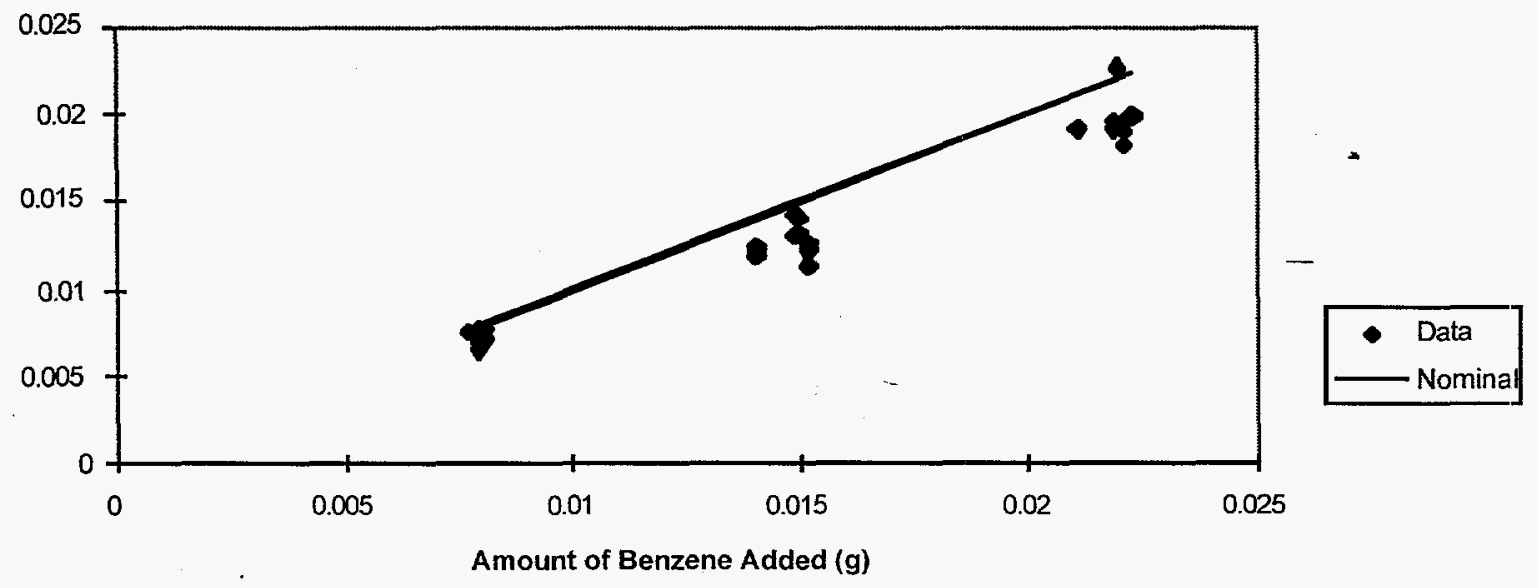


WSRC-TR-97-00362

Revision 0

Page 7 of 24

November 13, 1997

Figure 8. Vapor Phase Benzene Results with Respect to Time
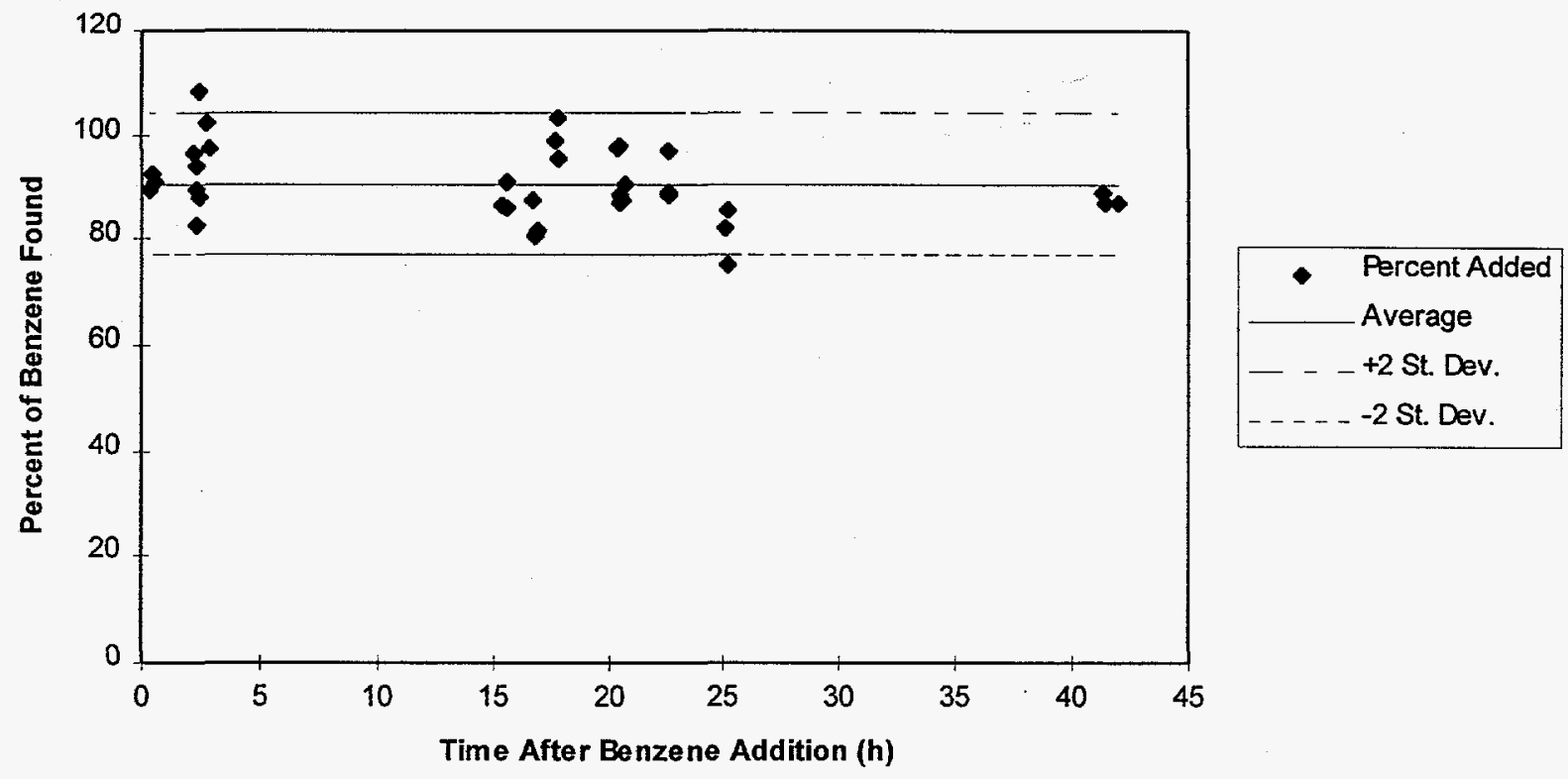

Figure 9. Benzene Solubility Results in Water at Room Temperature with Measured Liquid Benzene Concentrations

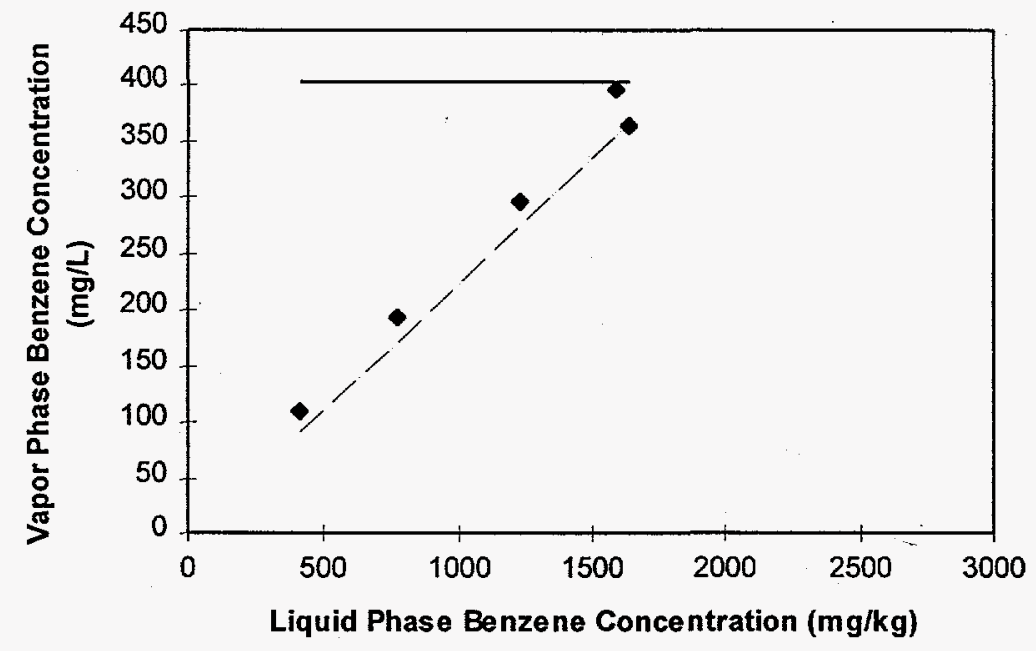

- Measured Data Saturated Benzene Henry's Law 
Figure 10. Benzene Solubility Results in Water at Room Temperature with Calculated Liquid Benzene Concentrations

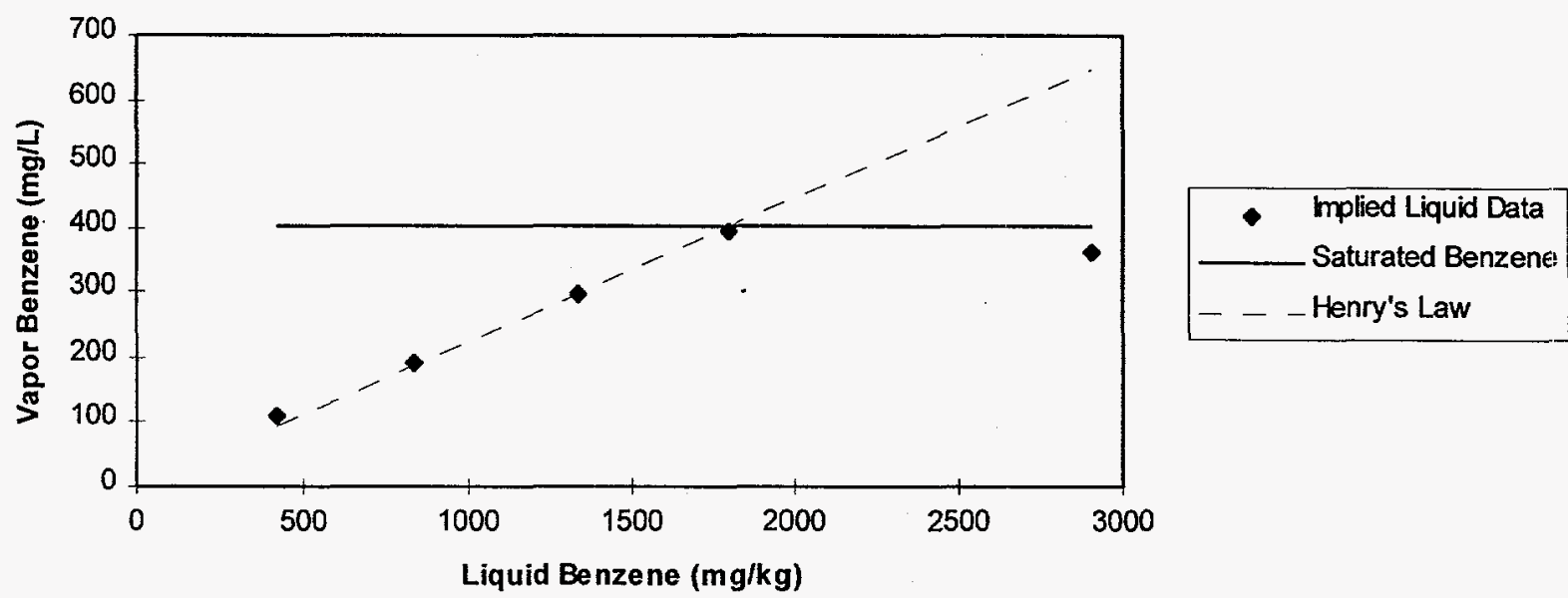

\section{Initial Test Method Results}

As stated above, the initial tests used a method that measured both the slurry and vapor phase benzene concentrations. The original scope of tests included 5 test sequences with the majority of the tests run at $35^{\circ} \mathrm{C}$. The first of these test sequences examined the impact of salt solution contents (i.e., $\mathrm{Na}^{+}$and $\mathrm{OH}^{-}$concentrations on the apparent solubility of benzene in KTPB slurries). The effect of sludge and titanate solids on the solubility of benzene in filtrate and slurry was investigated in Test Sequence \#2. Researchers planned to examine the impact of slurry irradiation and high temperatures in the third test sequence; this sequence was to look at apparent benzene solubility in the Late Wash process and therefore, a low sodium concentration slurry was to be used. Researchers investigated the impact of tetraphenylborate degradation intermediates (i.e., triphenylboron, diphenylborinic acid and phenylboric acid) and surfactants used in the tank farm (e.g., tri-n-butyl phosphate, Surfynol ${ }^{\mathrm{M}} 420$ and DoCorning 544, H-10 and Emulsion B) on the apparent solubility of benzene in KTPB slurry in the fourth test sequence. The effect of solids contents between 1 and $12 \mathrm{wt} \%$ solids and temperatures between $25^{\circ} \mathrm{C}$ and $50^{\circ} \mathrm{C}$. were to have been examined in Test Sequence \#5.

Several problems exist with the initial test method. The tests at $\sim 35^{\circ} \mathrm{C}$, above the ambient temperature $\left(\sim 21^{\circ} \mathrm{C}\right)$ for the lab module. Since the method initially used syringes at room temperature to extract samples, the temperature difference led to some condensation of benzene in syringes for samples with high benzene concentrations. In sorne cases this additional benzene condensate increased the measured benzene concentration to levels well in excess of the saturation concentration. This problem was recognized, and the syringes later warmed to $55^{\circ} \mathrm{C}$ (i.e., the maximum temperature allowed for handling without protection) to eliminate this problem. Vapor phase benzene measurements agreed much better with expected values with this change, but the problem was not entirely eliminated. A second problem with the initial test method involved inconsistency in the measured slurry benzene concentration results. Unfortunately, no immediately available way of combating this problem existed. A final problem with the initial test method involved the potential for leakage from the vessels. In this method, only a single Teflon-lined septum separated the slurry vapor space and the atmosphere. Due to multiple piercing of the septum during each test, the potential for leakage of the benzene increased. Large leakage could reduce the apparent equilibrium vapor phase benzene concentration with respect to the liquid phase benzene concentration. The second test method controlled this problem by adding a Teflon stopcock between the slurry and the septum. The stopcock was only open when adding benzene or sampling the vapor space. 
Test Sequence \#1 from Reference 7 examined the effect of salt solution composition on benzene retention in slurry. The tests used slurry containing $\sim 6.5 \mathrm{wt} \% \mathrm{KTPB}$ solids with $\sim 4.65 \mathrm{M} \mathrm{Na}^{+}$and an average $\mathrm{OH}^{-}$content, with $5 \mathrm{M}$ $\mathrm{Na}^{+}$and a high $\mathrm{OH}^{-}$content and with $5 \mathrm{M} \mathrm{Na}^{+}$with a low $\mathrm{OH}^{-}$content. Slurries with $2 \mathrm{M} \mathrm{Na}^{+}$and an average $\mathrm{OH}^{-}$ content and $0.2 \mathrm{M} \mathrm{Na}^{+}$and an average $\mathrm{OH}$ content were also tested. Table 1 gives the salt contents of these slurries. The tests occurred at a temperature of $-35^{\circ} \mathrm{C}$. Figures 11A and 11B graph the results. Previous work estimates the benzene saturation for $4.65 \mathrm{M}$ and $5 \mathrm{M} \mathrm{Na}^{+}$salt solution as approximately $200 \mathrm{mg} / \mathrm{kg}^{3}$; saturation for the $0.2 \mathrm{M} \mathrm{Na}^{+}$salt solution would approach the benzene saturation in water of approximately $2,000 \mathrm{mg} / \mathrm{kg}^{10}$. Benzene saturation for the $2 \mathrm{M} \mathrm{Na}^{+}$salt solution would fall somewhere between these two values. Though the results contain considerable scatter at high benzene concentrations, the $4.65 \mathrm{M} \mathrm{Na}^{+}$, average $\mathrm{OH}$ slurry and the $5 \mathrm{M}$ $\mathrm{Na}^{+}$, high hydroxide slurry do appear to give benzene saturation results close to $200 \mathrm{mg} / \mathrm{kg}$, and the $0.2 \mathrm{M} \mathrm{Na}^{+}$ slurry appears to give a benzene saturation value close to $1800 \mathrm{mg} / \mathrm{kg}$ (Figure 11A). Unfortunately, the results for the other two slurries tested prove inconclusive (Figure 11B).

Table 1. Final Dissolved Salt Composition of Slurries to be Tested

\section{Concentration in $4.65 \mathrm{M} \mathrm{Na}^{+}$ Salt Solution- Avg. Hydroxide (M)}

Concentration
in $5 \mathrm{M} \mathrm{Na}^{+}$Salt
Solution- Low
Hydroxide $\underline{(\mathrm{M})}$

Concentration
in $5 \mathrm{M} \mathrm{Na}{ }^{+}$Salt
Solution - High
Hydroxide $\underline{(\mathrm{M})}$

\author{
Concentration \\ in $2 \mathrm{M} \mathrm{Na}^{+}$Salt \\ Solution - Avg. \\ Hydroxide (M)
}

Concentration in $0.1 \mathrm{M} \mathrm{Na}^{+}$ Salt SolutionAvg. Hydroxide (M) 0.066 0.094 0.023 0.016

0.13

0.06

0.07

$\underline{0.0001}$ 2.0 
Page 10 of 24

November 13, 1997

Figure 11A. Results of Sequence \#1 Tests from Initial Test Method with Regression of Low Concentration Data

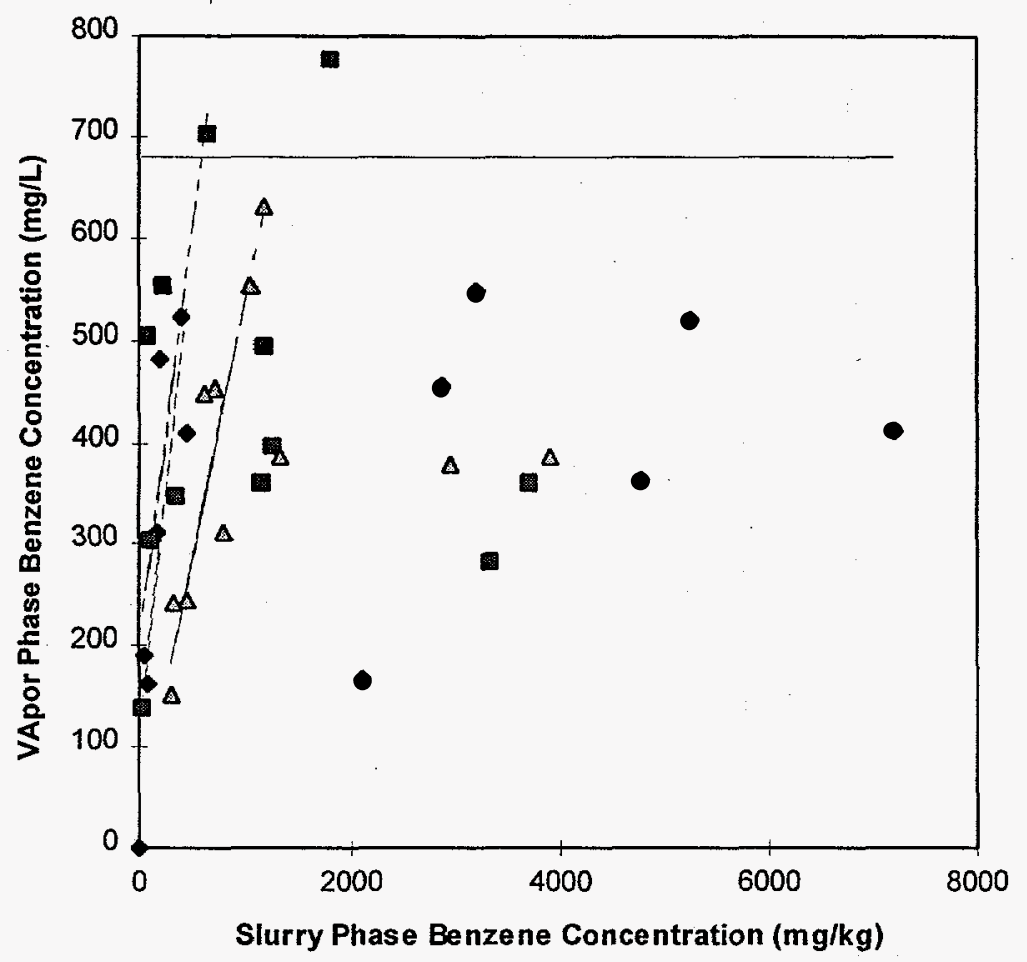

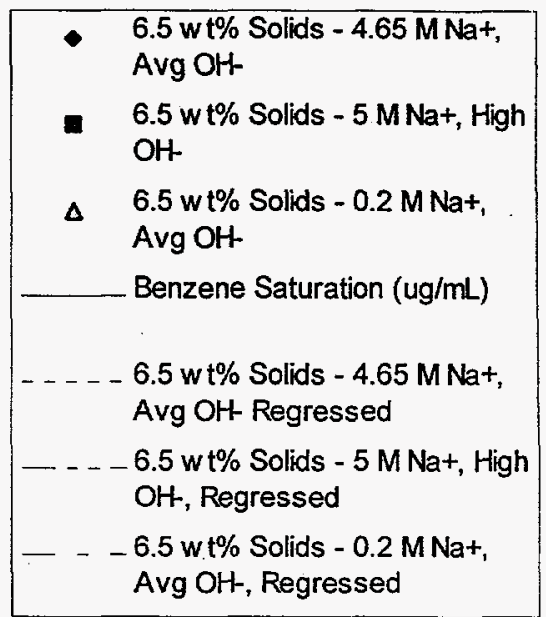

Figure 11B. Results of Sequence \#1 Tests from Initial Test Method with No Regression

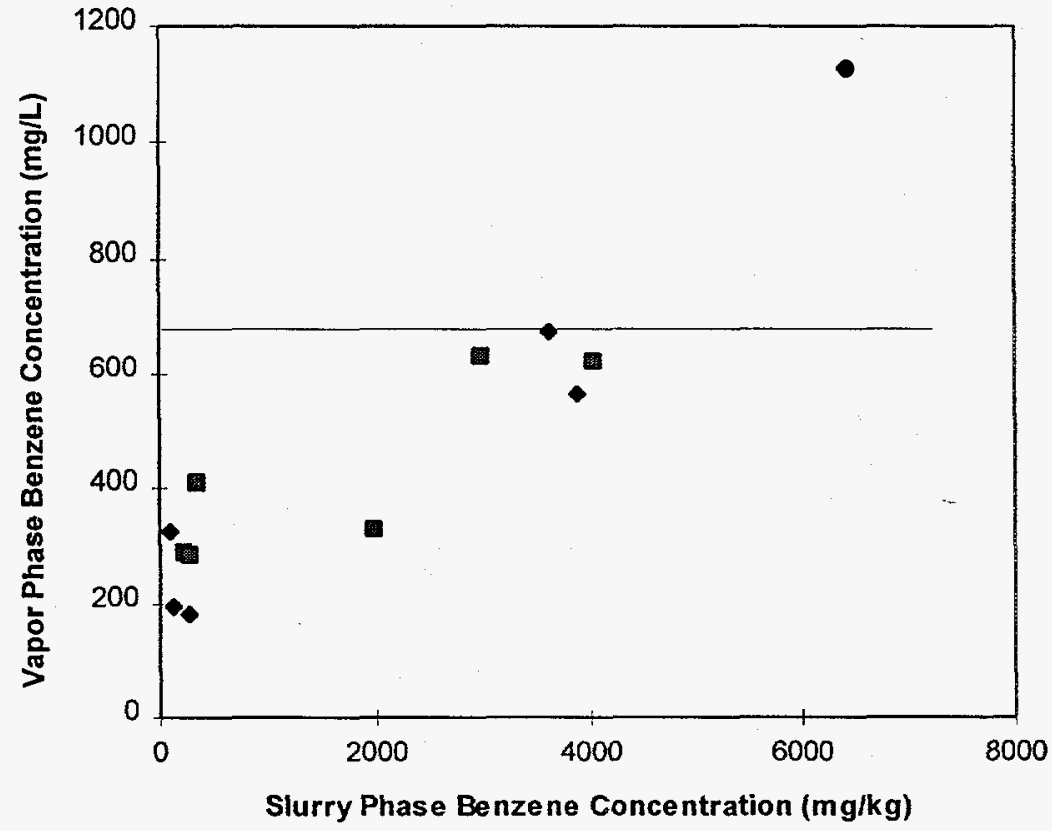

- $6.5 \mathrm{w}$ t\% Solids - $5 \mathrm{MNa}+$, Low $\mathrm{OH}$

$6.5 w$ t\% Solids - $2 \mathrm{M} \mathrm{Na}$, Avg $\mathrm{OH}$

Benzene Saturation ( $\mathrm{ug} / \mathrm{mL}$ ) 
Test Sequence \#2 using the initial method examined the effect of sludge and titanate solids on both $4.65 \mathrm{M} \mathrm{Na}^{+}$salt solution alone and on salt solution containing $6.5 \mathrm{wt} \% \mathrm{KTPB}$ solids. ${ }^{7}$ Figure 12 gives the results. Again, though noisy, the results indicate no appreciable difference in benzene solubility between salt solution containing no solids and salt solution containing either $6,000 \mathrm{mg} / \mathrm{L}$ simulated Purex sludge or $2,000 \mathrm{mg} / \mathrm{L}$ monosodium titanate.

Additionally, $6.5 \mathrm{wt} \%$ solids KTPB slurry in $4.65 \mathrm{M} \mathrm{Na}^{+}$salt solution with either sludge or titanate gives a benzene solubility not appreciably different from that of salt solution alone.

Figure 12. Results of Sequence \#2 Tests from the Initial Test Method

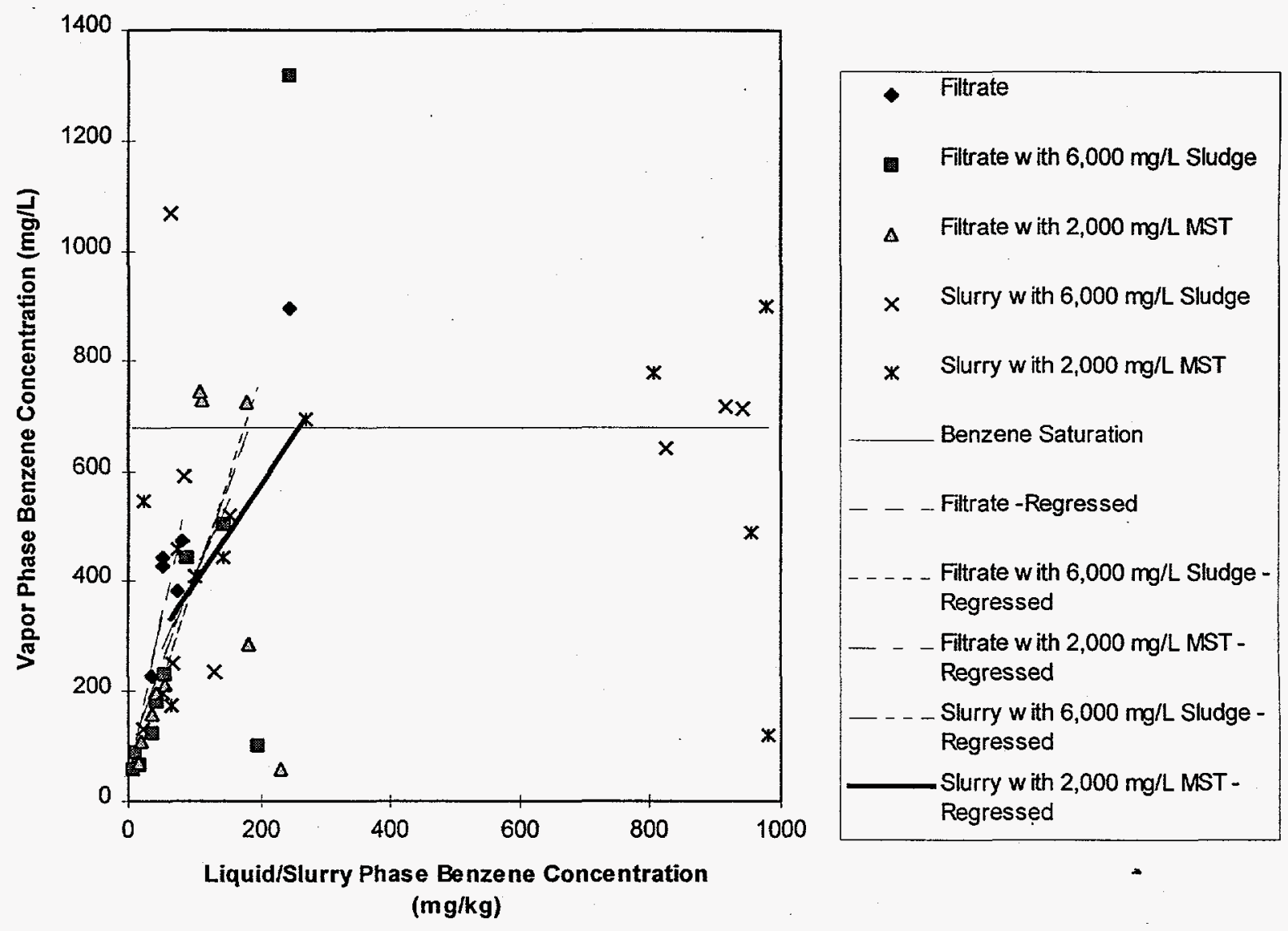

Test Sequence \#4 of the initial test method examined the variance in the solubility of benzene in $6.5 \mathrm{wt} \%$ solids KTPB slurry in the presence of tetraphenylborate degradation intermediates and several surfactants used in the High Level Waste process. ${ }^{7}$ The slurry used to examine the effects of TPB intermediates contained 4,200 mg/L of triphenylboron (3PB), $510 \mathrm{mg} / \mathrm{L}$ of diphenylborinic acid (2PB) and $1,500 \mathrm{mg} / \mathrm{L}$ of phenylboric acid (1PB). The slurries used to examine the effects of surfactants contained either $100 \mathrm{mg} / \mathrm{L}$ of tri-n-butyl phosphate, 2,000 mg/L of Surfynol ${ }^{\mathrm{TM}} 420$ or $100 \mathrm{mg} / \mathrm{L}$ each of Dow-Corning 544, Dow-Corning H-10 and Dow-Corning Emulsion B. Figure 13 provides the results. The results proved too noisy to draw any conclusion. 
Figure 13. Results of Sequence \#4 Tests from Initial Test Method

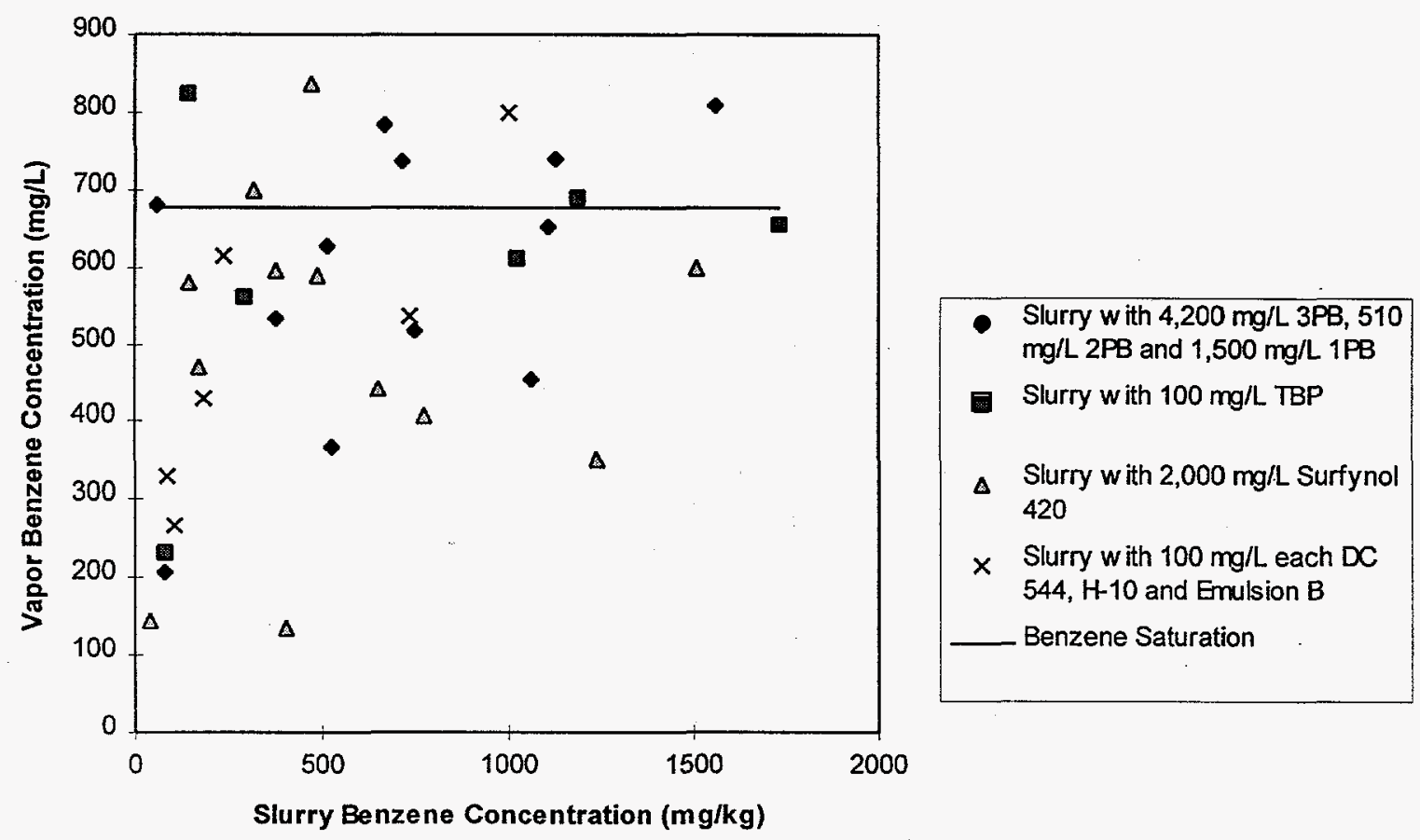

Test Sequence \# 3 was planned to examine the effect of radiation and high temperature on the solubility of benzene in KTPB slurry. ${ }^{7}$ Test Sequence \#5 was planned to examine the effect of KTPB solids content and temperature on the solubility of benzene. ${ }^{7}$ However, as a result of the problems encountered with the initial test sequences, the authors decided to discontinue use of the experimental method.

\section{Results of Second Test Method}

The authors adopted a second test method using the vessel shown in Figure 6. Also, the scope was modified due to knowledge gained from the first tests. ${ }^{9}$ Since the results from the original method indicated no apparent suppression of benzene vapor pressure over KTPB slurry, the scope of testing was reduced to verify no vapor pressure suppression effect with the addition of KTPB solids and to examine the effect of the various additives. More expansive testing of the effects of solids content and other variables remained in Reference 9 as an optional addition should further detail be desired. Testing at higher temperatures was also eliminated because lack of any apparent solubility effect would imply that the temperature effect is predictable (i.e., it would be the same as for benzene in salt solution alone) and because of the difficulties encountered with getting accurate vapor phase measurements at those conditions.

For the second test method, Test Sequence \#1 established a baseline by examining the solubility of benzene in $4.65 \mathrm{M} \mathrm{Na}^{+}$salt solution. Table 1 gives the composition of this salt solution. For each of the filtrate samples, the benzene concentration was measured on the two consecutive days to verify equilibrium. Figure 14 shows the results. The dashed line represents a regression of measured vapor and liquid phases. The discrete points represent measured vapor phase concentrations and implied liquid phase concentrations (i.e., total benzene added minus the amount found in the vapor phase divided by the liquid/slurry mass). The implied results shown represent the 
average of the two values for each sample. The shaded area was derived from the difference between the measured and implied liquid concentration results and represents the area where benzene solubility data for a solution or slurry with a benzene solubility the same as that of our $4.65 \mathrm{M} \mathrm{Na}^{+}$filtrate might be expected to fall with a $95 \%$ confidence level. For comparison, this data is included in the graphs of all the other results. The saturation vapor phase benzene concentration and Henry's Law liquid-vapor phase benzene concentration relationship inferred from previous work conducted by Walker ${ }^{3}$ are also given. The difference between the Walker Henry's Law line and our data result from small differences in the salt solutions.

Test Sequence \#2 examined the effect of the addition of KTPB solids on the solubility of benzene in salt solution. Figure 14 shows the results. For each benzene concentration, two test vials were prepared. The vapor phase benzene concentration in each vial was measured on three consecutive days to verify equilibrium. The average standard deviation of each of those sets of three measurements was $6.5 \%$. There was no uniform trend in the changing concentrations. The three measurements for each test vial were averaged; the averages are given in Figure 14. These results indicate no apparent benzene solubility effect in KTPB slurry.

Figure 14. Results of Sequences \#1 and \#2 Tests Using the Second Test Method

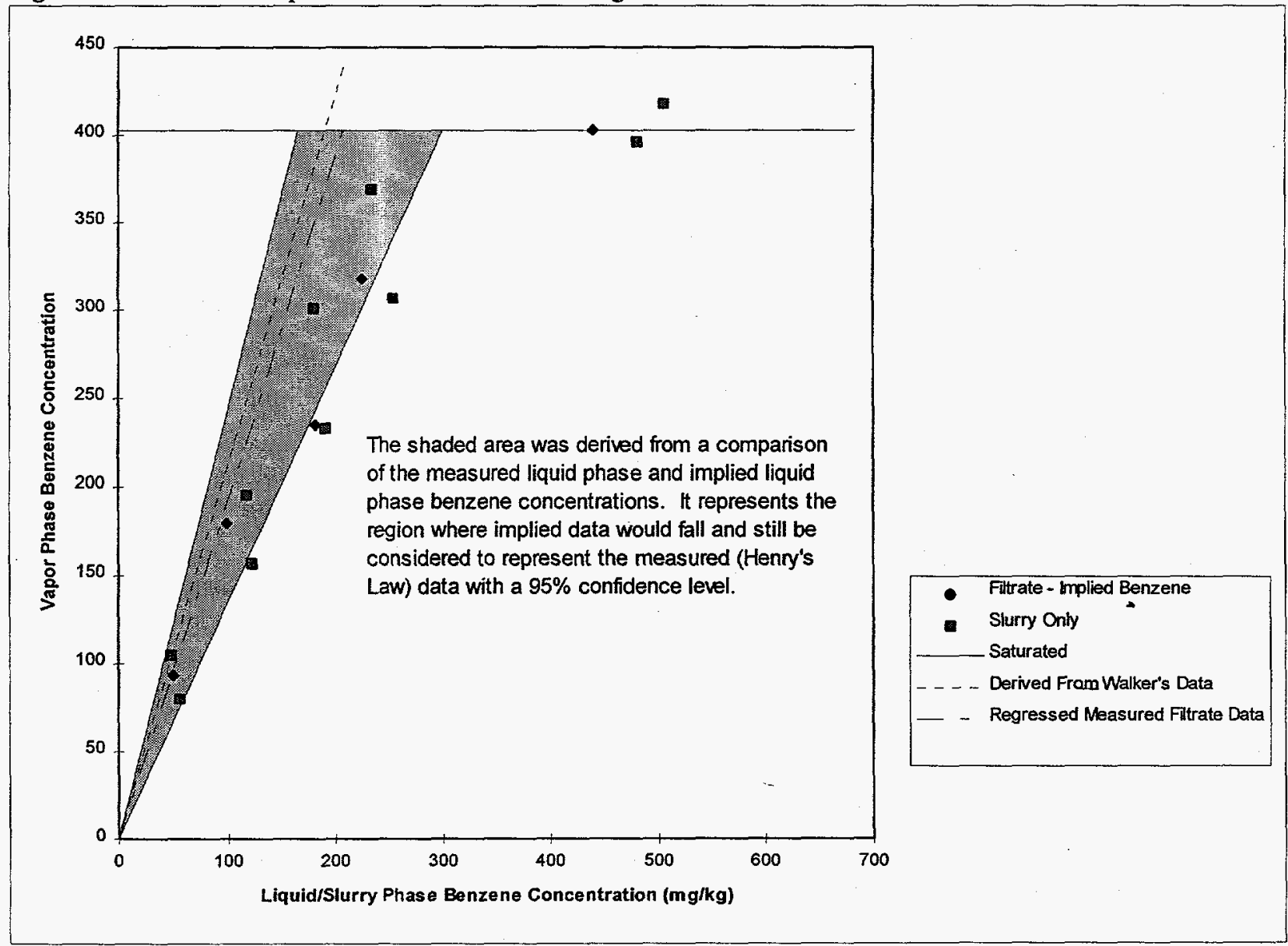

Test Sequence \#3 of the second test method examined the effect of $6,000 \mathrm{mg} / \mathrm{L}$ sludge and $2,000 \mathrm{mg} / \mathrm{L}$ titanate solids on the solubility of benzene in the same KTPB slurry as used above. In this sequence, five test vials were prepared containing different amounts of benzene. The benzene concentration in each test vial was measured one 
day and three days after preparation of the vials. The vials showed an average of $9 \%$ decrease in vapor phase benzene concentration from the first to the second sample. The results from the two measurements for each of the test vials were averaged and are presented in Figure 15. Again the benzene solubility results show no significant deviation from the solubility of benzene in salt solution.

Figure 15. Results Sequence \#3 Tests Using the Second Test Method

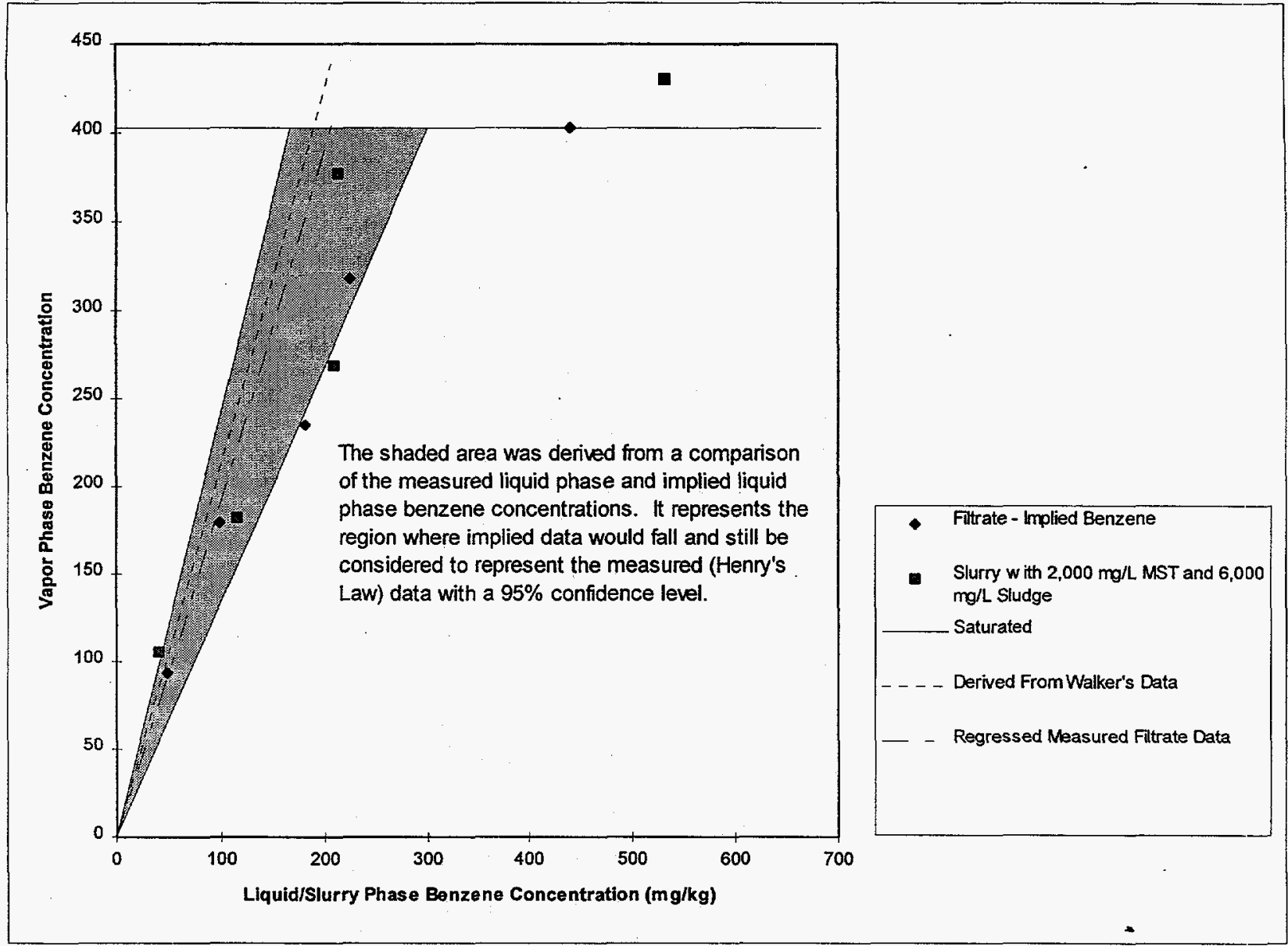

The effect of TPB intermediates was examined in Test Sequence \#6. Researchers mixed the standard $6.5 \mathrm{wt} \%$ KTPB slurry with $4,200 \mathrm{mg} / \mathrm{L}$ of $3 \mathrm{~PB}, 510 \mathrm{mg} / \mathrm{L}$ of $2 \mathrm{~PB}$ and $1,500 \mathrm{mg} / \mathrm{L}$ of $1 \mathrm{~PB}$ in five test vials along with varying amounts of benzene. The amounts of intermediates used reflected the maximum concentrations of these intermediates expected in the process. ${ }^{9}$ As with previous tests, the benzene concentration in each of the three vials was measured on consecutive days starting one day after the test vials were prepared. The values for the two measurements for each of the test vials were averaged with the results given in Figure 16. As with previous results, the TPB intermediates appear to have negligible effect on benzene solubility in the slurry. 
Figure 16. Results of Sequence \#6 Tests Using the Second Test Method

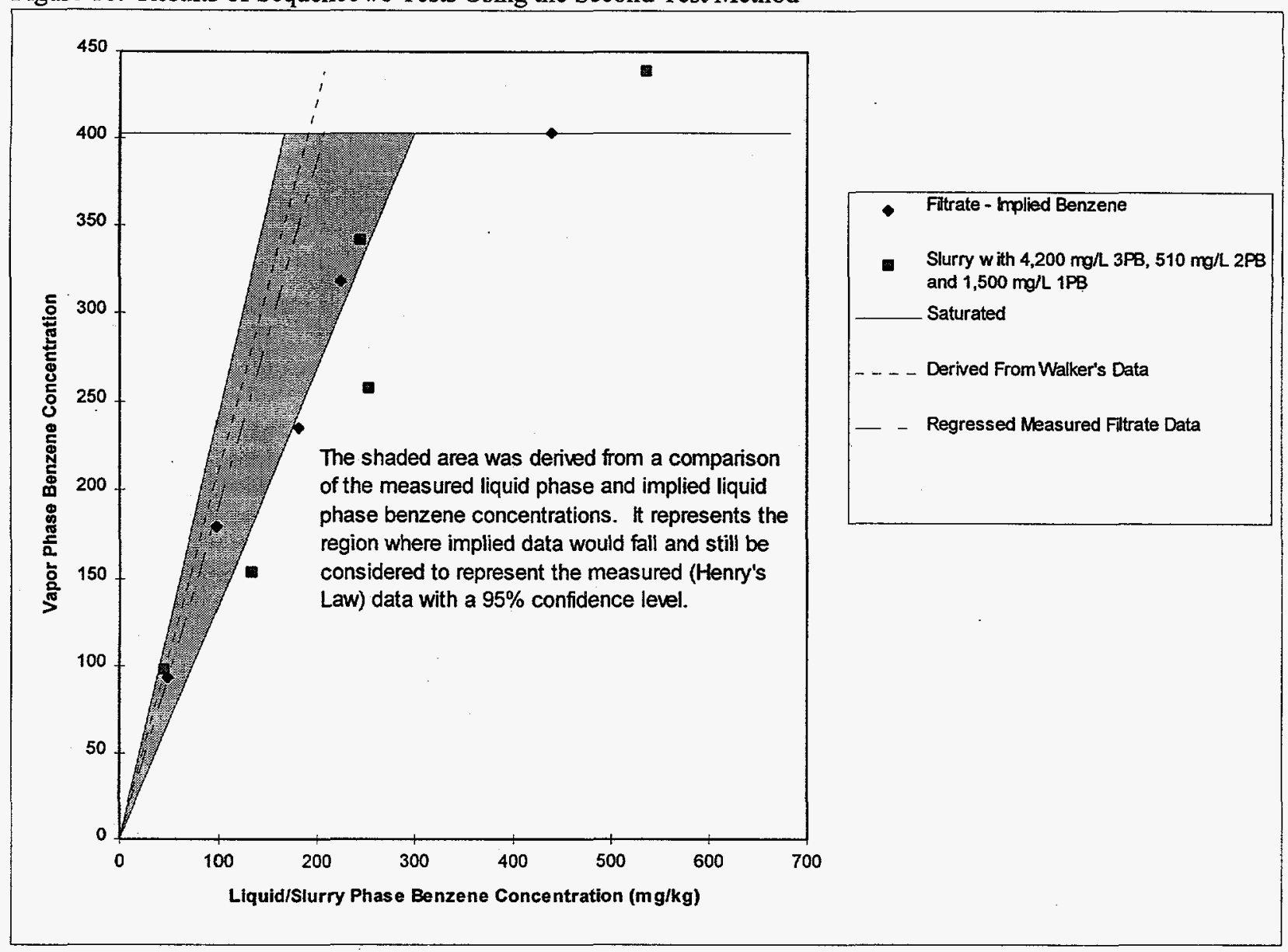

Test Sequence \#5 examined the effect of $100 \mathrm{mg} / \mathrm{L}$ tri-n-butyl phosphate (TBP) on the solubility of benzene in KTPB slurry. This amount of tri-n-butyl phosphate approximates the concentration which will be added to filtrate upstream of the ITP stripper to control foaming. Again, the same $6.5 \mathrm{wt} \%$ KTPB slurry was used and five test vessels with varying benzene concentrations were prepared. Benzene concentration measurements were taken on consecutive days starting one day after preparation of the test vials. The results of the two measurements for each test vial were averaged with the averages given in Figure 17. The results appear to indicate little if any vapor pressure suppression of benzene in the slurry. However, previous work indicated a significant suppression of benzene vapor pressure in the presence of large quantities of tri-n-butyl phosphate. ${ }^{10}$ Because TBP is relatively insoluble in salt solution and would float on salt solution or slurry, large quantities could accumulate in tanks downstream of the ITP stripper. Further testing would help to quantify the magnitude of this effect. 
Figure 17. Results of Sequence \#5 Tests Using the Second Test Method

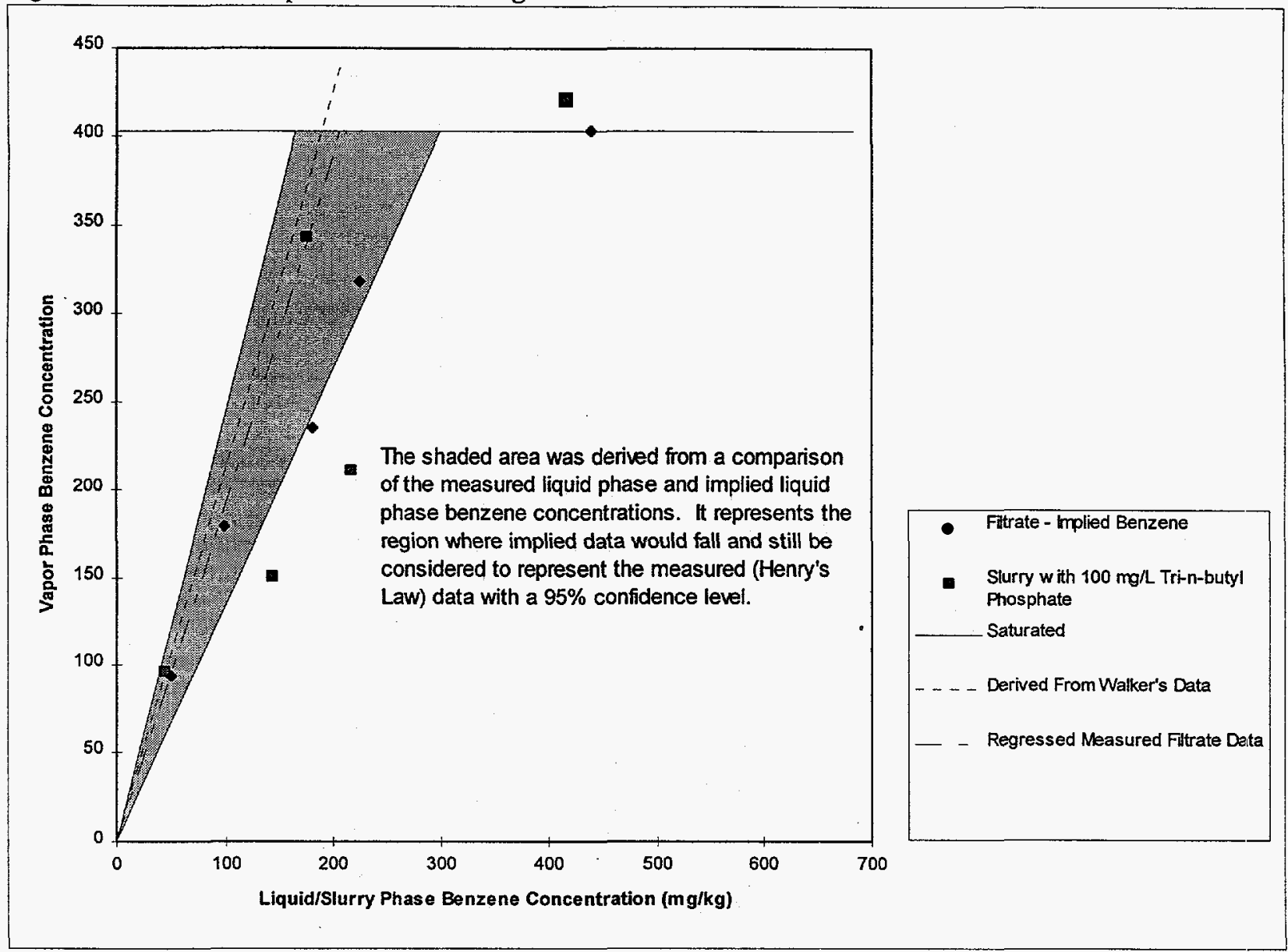

The effect of $2,000 \mathrm{mg} / \mathrm{L}$ of Surfynol ${ }^{\mathrm{TM}} 420$ on the solubility of benzene in $6.5 \mathrm{wt} \% \mathrm{KTPB}$ slurry was investigated in Test Sequence \#7. This concentration of Surfynol ${ }^{\top M} 420$ reflects the concentration expected to be added to control foaming in the Late Wash process; the concentrations expected to reach ITP as part of the recycle stream are much smaller. ${ }^{9}$ Five tests were conducted with varying benzene concentrations. The vapor phase benzene concentrations in the vessels were measured at 1 and 2 days after preparation of the vessels. The average results of the two analyses for each vessel are shown in Figure 18. The results of this test show a strong benzene vapor pressure suppression effect. This effect likely results from the dilution of benzene by the Surfynol ${ }^{\mathrm{TM}} 420$. If this effect causes the benzene vapor pressure suppression, the benzene vapor-liquid equilibrium in a benzene-Surfynol ${ }^{\mathrm{TM}} 420$ mixture would obey the following relationship.

$$
P P_{B z}=V P_{B z}\left(\frac{x_{B z}}{x_{B z}+x_{S}}\right),
$$

where $P P_{B z}=$ the partial pressure of benzene,

$V P_{B z}=$ the saturation pressure of benzene,

$x_{B z}=$ the moles of benzene in the benzene-Surfynol ${ }^{\top M} 420$ solution and

$x_{S}=$ the moles of Surfynol ${ }^{\mathrm{TM}} 420$ in the benzene-Surfynol ${ }^{\mathrm{TM}} 420$ solution. 
This treatment considers only the benzene-Surfynol ${ }^{\mathrm{TM}} 420$ system and assumes that that system follows Raoult's Law. Any deviation from Raoult's Law would cause a difference between the predicted and measured concentration values. Researchers also ignored any benzene or Surfynol ${ }^{\mathrm{TM}} 420$ that might be dissolved in the aqueous phase, and any other effects of the slurry phase. Figure 19 plots the benzene vapor pressure from this relationship along with the measured benzene concentrations. The shapes of the curves in the area studied are about the same, but the theoretical vapor concentrations are offset low with respect to the measured values. This may be the result from the assumptions discussed above. A example calculation of the theoretical vapor pressure of benzene in the Surfynol ${ }^{\mathrm{TM}} 420$-benzene system is provided in the Appendix.

Figure 18. Results of Sequence \#7 Tests Using the Second Test Method

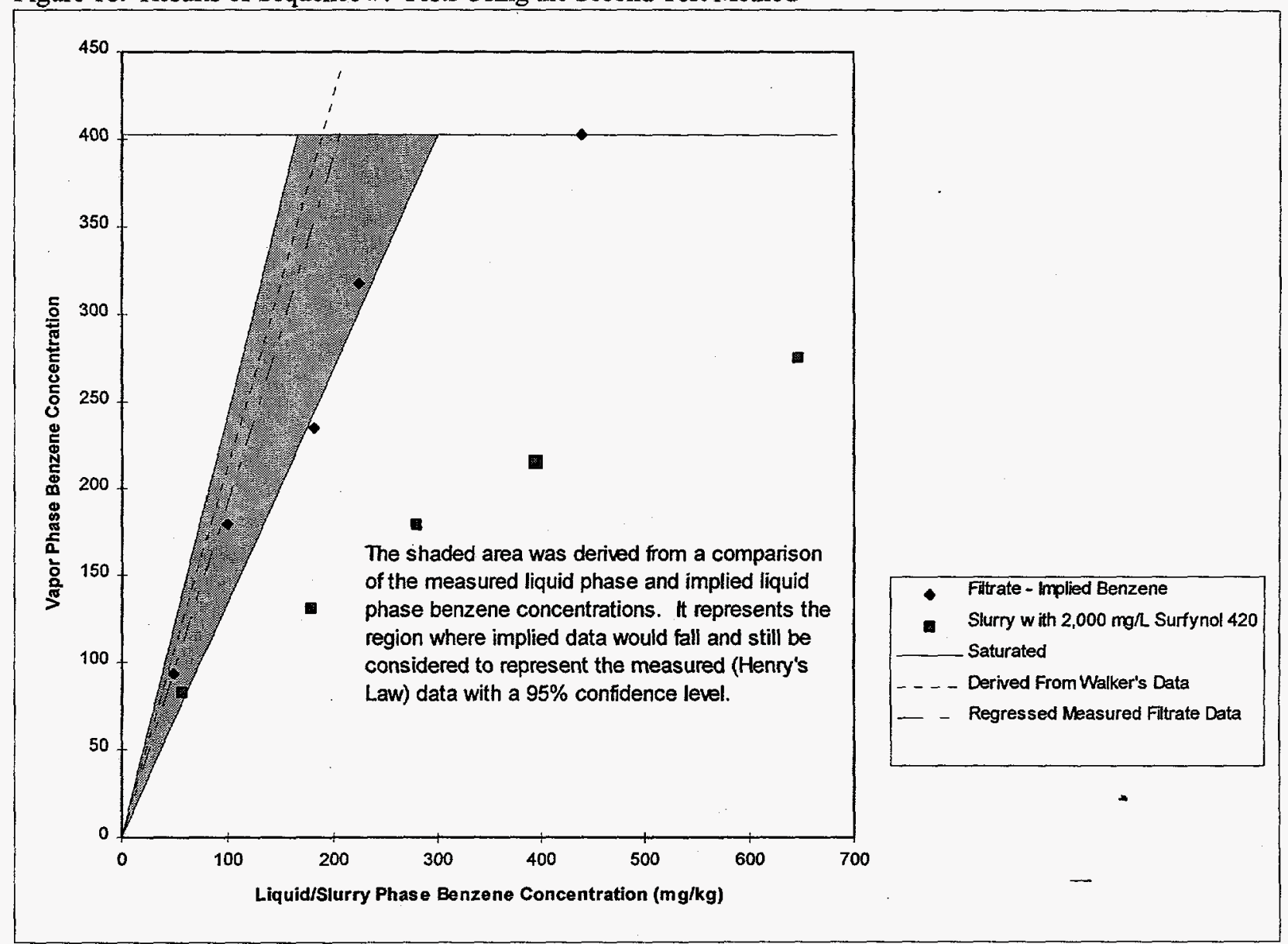


Figure 19. Theoretical and Measured Vapor Phase Benzene Concentrations Over 6.5 wt \% KTPB Slurry Containing $2,000 \mathrm{mg} / \mathrm{L}$ Surfynol ${ }^{\mathrm{TM}} 420$

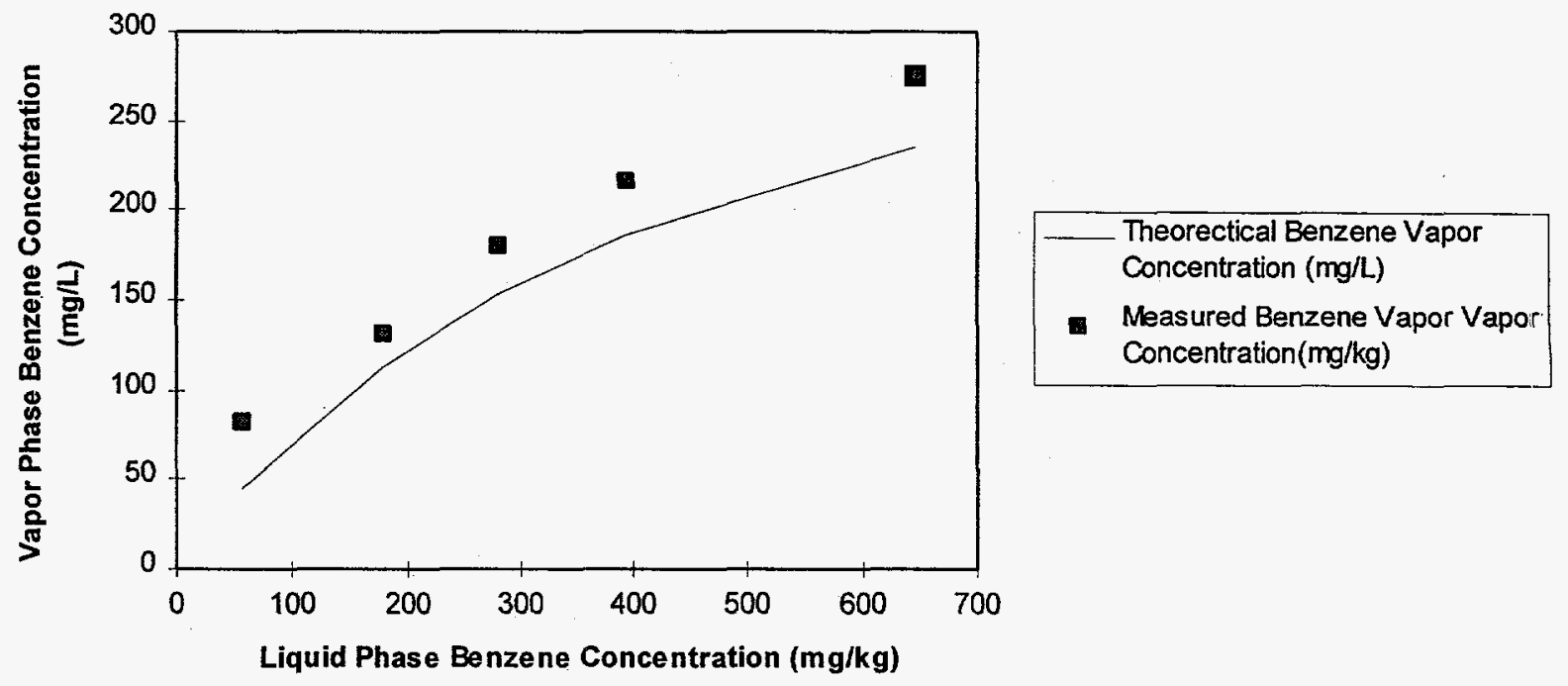

The Sequence \#4 tests used slurry irradiated to $95 \mathrm{Mrad}$ in the Gamma Cell. Similar amounts of benzene were added to the five test vessels as added in the previous tests. The benzene concentration was measured both one day and four days after the test vessels were prepared. The vapor phase concentrations increased an average of $14 \%$ during that period. The results of the Sequence \#4 tests are shown in Figure 20. As with the Surfynol ${ }^{\mathrm{TM}} 420$ tests, there is obvious vapor pressure suppression. This suppression likely results from dilution of the benzene with biphenyl that accumulates during the irradiation. The slurry was analyzed for biphenyl concentration with the result given in Table 2.

Because of the vapor pressure suppression seen in Sequence \#4, it was decided to initiate Test Sequences \# 8, 9 and 10 with the slurry irradiated to 30,60 and $120 \mathrm{Mrad}$, respectively. Also, because of the vapor pressure suppression noted in Sequence \#4, larger amounts of benzene were used in the later test sequences. Figure 20 gives the results of all four sequences. The results of these tests indicate the existence of vapor pressure suppression that increases with irradiation exposure. Because the vapor pressure suppression in the irradiated slurries presumably results from the same mechanism as vapor pressure suppression in slurry with Surfynol ${ }^{T M} 420$, it should also obey Equation (1). Figure 21 shows the results of these test sequences along with the predicted theoretical values. The calculations used to produce the predicted curves are given in the Appendix. The shapes of the curves are similar, but again there appears to be an offset. The offset is not as consistent as the offset in the slurries containing-SurfynolTM 420 . Since the biphenyl is insoluble in aqueous solutions, the difference between the predicted and measured vapor pressure of benzene probably results from nonideality of the system with respect to Raoult's Law, from experimental variability, and from any benzene which might be dissolved in the aqueous phase. 
WSRC-TR-97-00362

Revision 0

Page 19 of 24

November 13, 1997

Table 2: Biphenyl Concentrations in the Irradiated Slurries

Slurry Exposure (Mrad)

30

60

95

120
Biphenyl Concentration (mg/L)

1,903

2,411

3,000

3,365

Figure 20. Results of the Sequence \#'s 4, 8, 9 and 10 Tests Using the Second Test Method

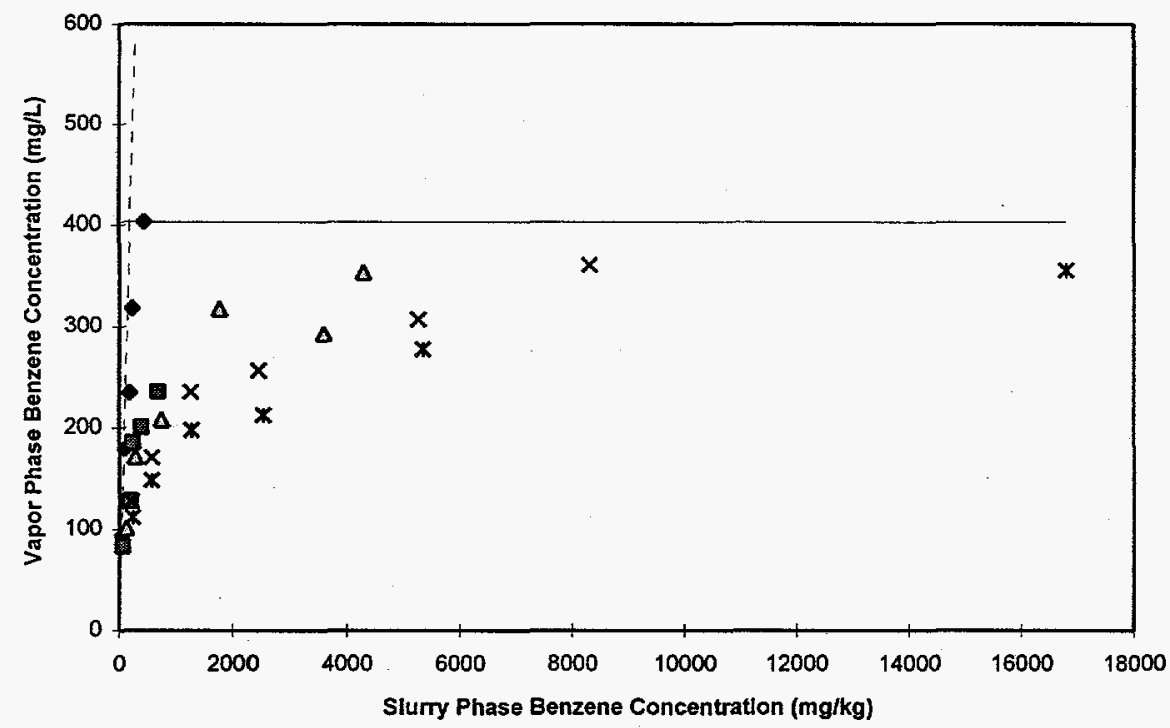

\begin{aligned} - Filtrate \\ Slurry Irradiated to $95 \mathrm{Mrad} \\$ A Slurry Irradiated to $30 \mathrm{Mrad} \\ \times \quad$ Slumy Irradiated to $60 \mathrm{Mrad} \\$ X Slumy Irradiated to $120 \mathrm{Mrad} \\$\hline\end{aligned}


Figure 21. Theoretical and Measured Vapor Phase Benzene Concentrations Over Irradiated 6.5 wt \% KTPB Slurry
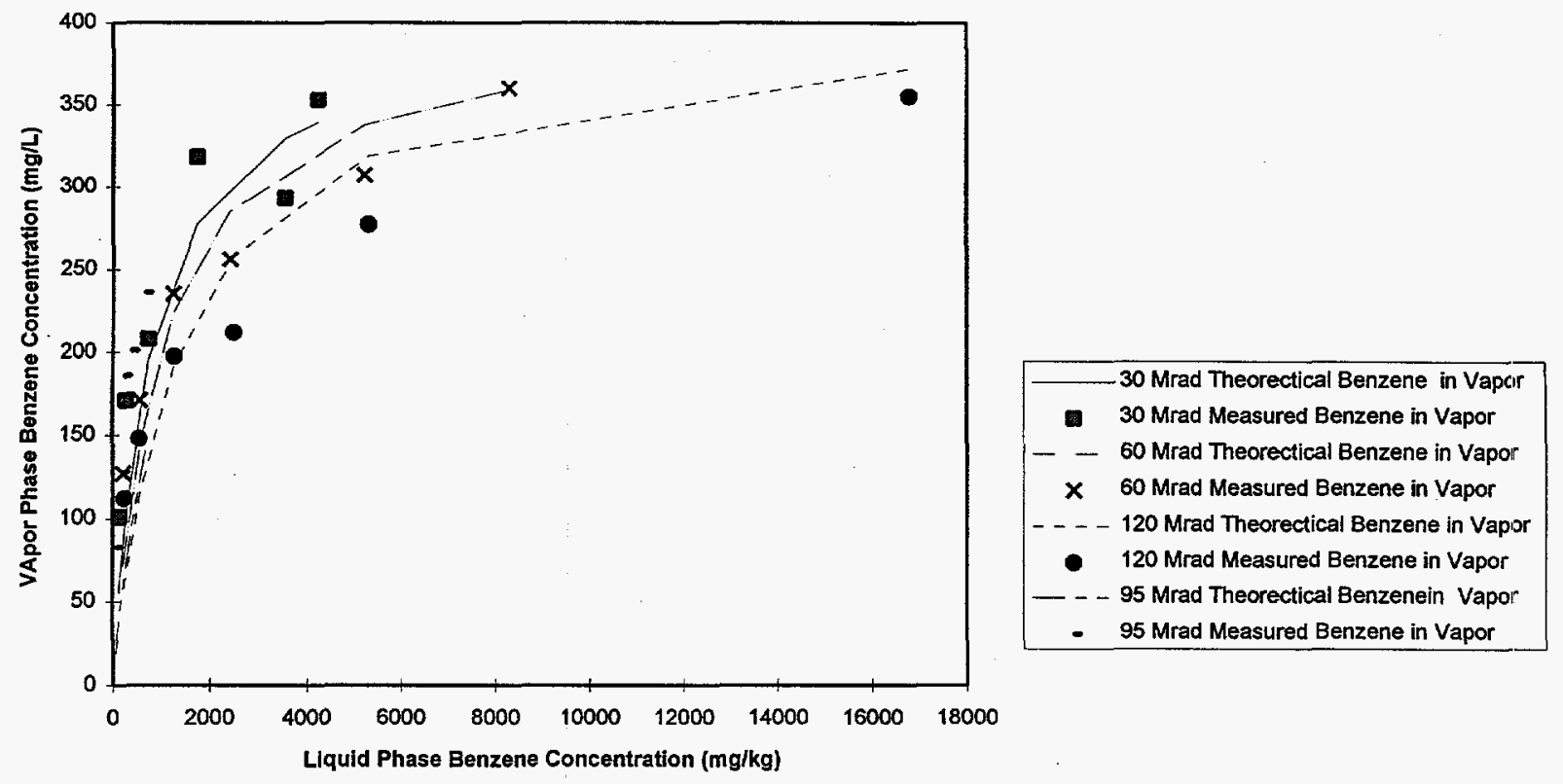

\section{CONCLUSIONS}

From these tests, it appears that KTPB solids alone do not appreciably affect the solubility of benzene in salt solution. The same is true of sludge solids, monosodium titanate and TPB decomposition intermediates. In low concentrations the same appears true for tri-n-butyl phosphate. However, large quantities of materials soluble in benzene, such as Surfynol ${ }^{T M} 420$, biphenyl and other radiolytic decay products of KTPB can significantly affect the solubility of benzene in KTPB slurry and significantly reduce the vapor pressure.

\section{QUALITY ASSURANCE}

The work documented in this report was performed under Task Technical Plan WSRC-RP-96-775, Revisions 0 and $1^{7,9}$ and Task QA Plan WSRC-RP-96-776, Revision $0^{8}$. Instructions and results are documented in Lab Notebooks WSRC-NB-95-308, WSRC-NB-96-611, WSRC-NB-97-00494 and WSRC-NB-97-493.

\section{REFERENCES}

1. D. D. Walker, M. J. Barnes, C. L. Crawford, R. F. Swingle, R. A. Peterson, M. S. Hay, and S. D. Fink, "Decomposition of Tetraphenylborate in Tank 48H (U)", WSRC-TR-96-0113, Rev. 0, May 10, 1996

2. H. D. Harmon, W. L. Tamosaitis, S. D. Fink, R. A. Peterson, D. D. Walker, M. J. Barnes, C. L. Crawford, R. F. Swingle, and M. S. Hay, "ITP Benzene Generation and Release Model (U)", HLW-TEC-960016, June 18, 1996.

3. D. D. Walker, "Vapor Pressure of Benzene, Methanol, and Isopropanol Over Salt Solutions (U)", DPST88-661, March 28, 1989. 
5. A. W. Wiggins, "Apparent Benzene Solubility and VLE in KTPB Slurry", HLE-TTR-97017, Revision 0 , November 15, 1996.

6. A. L. Watkins, "DNFSB Recommendation 96-1 Implementation Plan", DOE-SR Memorandum to S. P. Cowan, October 21, 1996.

7. R. F. Swingle, "Task Technical Plan to Study the Effects of Solids on the Apparent Solubility of Benzene in Simulated ITP Salt Solutions (U)", WSRC-RP-96-775, Revision 0, December 16, 1996.

8. R. F. Swingle, "Task QA Plan to Study the Effects of Solids on the Apparent Solubility of Benzene in Simulated ITP Salt Solutions (U)", WSRC-RP-96-776, Revision 0, December, 19, 1996.

9. R. F. Swingle, "Task Technical Plan to Study the Effects of Solids on the Apparent Solubility of Benzene in Simulated ITP Salt Solutions (U)", WSRC-RP-96-775, Revision 1, October 20, 1997.

10 A. Seidell, Solubilities of Organic Compounds, $3^{\text {rd }}$ Edition, Volume I, New York, D. Van Nostrand Company, Inc., 1941.

11. R. F. Swingle, "Tri-n-butyl Phosphate Combustibility in In-Tank Precipitation Salt Solutions (U)", WSRC-RP-94-526, Revision 0, June 16, 1994.

12. J. P. Bibler and R. F. Swingle, "Testing Surfynol ${ }^{\mathrm{TM}} 420$ in Tank $48 \mathrm{H}$ and Tank $22 \mathrm{H}$ Simulants for Chemical and Radiolytic Effects (U)", WSRC-TR-96-0129, Revision 0, July 11, 1996.

13. John A. Dean, ed., Lange's Handbook of Chemistry, $13^{\text {th }}$ Edition, McGraw-Hill Book Co., New York, 1985.

14. D. R. Lide, ed., CRC Handbook of Chemistry and Physics, $76^{\text {th }}$ Edition, CRC Press, Boca Raton, FL, 1995. 
WSRC-TR-97-00362

Page 22 of 24

November 13, 1997

APPROVALS

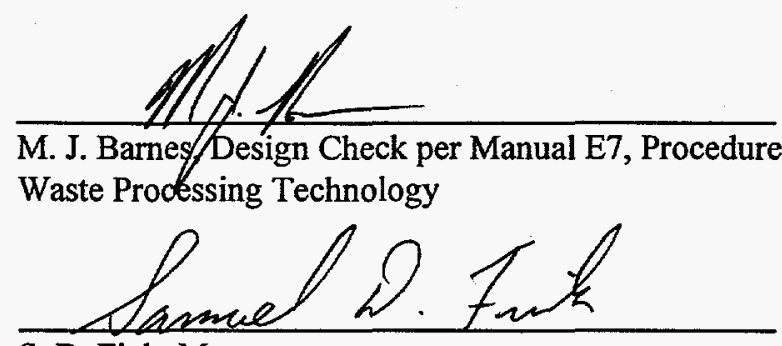

S. D. Fink, Manager

Liquid Waste Processing

W.B. San Pelt

W. B. Van Pelt, Manager

Waste Handling and Mechanical Processing

J. L. Barnes, Deputy Manager

Waste Pre-Treatment Engineering

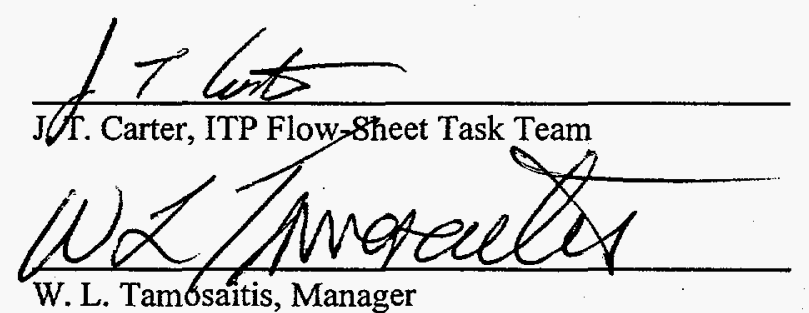

W. L. Tambsaitis, Manager Waste Processing Technology
Revision 0
Date: $11 / 13 / 97$

Date: $11-17-q 7$

Date: $11-18-97$

Date: $11-19-97$

Date: $11-19-97$

Date:

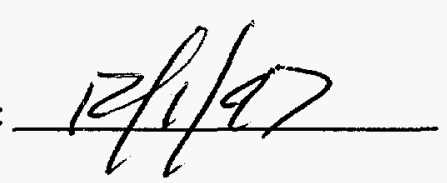




\section{APPENDIX}

\section{Prediction of Vapor Pressure of Benzene Containing Dissolved Organics}

This calculation assumes that any benzene not dissolved in the aqueous phase exists in a solution with the dissolved organic in question (e.g., Surfynol ${ }^{\mathrm{TM}} 420$ or biphenyl). The vapor pressure of the benzene above the mixture remains proportional to the mole fraction of the benzene in the benzene-organic solution according to equation (1) restated below.

$$
P P_{B z}=V P_{B z}\left(\frac{x_{B z}}{x_{B z}+x_{D}}\right)
$$

where $P P_{B z}=$ the partial pressure of benzene,

$V P_{B z}=$ the saturation pressure of benzene,

$x_{B z}=$ the moles of benzene in solution with the dissolved organic and

$x_{D}=$ the moles of the dissolved organic in the solution with the benzene.

This calculation assumes the dissolved organics discussed have negligible solubility in the aqueous phase with respect to the total amount added. Previous work shows the solubility of Surfynol ${ }^{\mathrm{TM}} 420$ as less than 25 ppm in salt solutions. ${ }^{12}$ Lange's Handbook of Chemistry lists biphenyl as insoluble in water. ${ }^{13}$

\section{$\underline{\text { Surfynol }}{ }^{\mathrm{TM}} 420$}

Given the following information:

Molecular Weight for Surfynol TM420: $283.63^{12}$

Molecular Weight for Benzene: $78.11^{13}$

Implied Benzene Concentration in Liquid (assumed all in Benzene-Surfynol ${ }^{\top \mathrm{M}} 420$ phase): $57.2 \mathrm{mg} / \mathrm{kg}$

Added Concentration of Surfynol ${ }^{T M} 420$ in liquid (assumed all in Benzene-Surfynol ${ }^{\top M} 420$ phase): 2,000 mg/L

Amount of Slurry/Liquid Phase: $30 \mathrm{~mL}$ with a density of $1.2 \mathrm{~g} / \mathrm{mL}$ (i.e., $36 \mathrm{~g}$ )

Vapor Pressure of Benzene at $25^{\circ} \mathrm{C}: 0.126 \mathrm{~atm}^{14}(403 \mathrm{mg} / \mathrm{L})$.

The total number of moles of Surfynol ${ }^{\mathrm{TM}} 420$ may calculated by:

Moles $=$ Concentration $($ mass $/$ volume $) *$ Liquid Volume $/$ Molecular Weight with appropriate unitary conversions

Moles Surfynol ${ }^{\mathrm{TM}} 420=(2,000)^{*}(30 / 1000) / 1000 / 283.63=0.000211$

The total number of moles of Benzene may be calculated by:

Moles $=$ Concentration (mass/mass) $*$ Liquid Weight $/$ Molecular Weight with appropriate unitary conversions.

Moles Benzene $=(57.2) *(36 / 1000) / 1000 / 78.11=0.0000264$ 
Using Equation (1) to calculate the vapor phase benzene concentration gives

Vapor Phase Benzene Concentration $=(403) *(0.0000264) /(0.0000264+0.000211)=44.8 \mathrm{mg} / \mathrm{L}$

\section{Biphenyl}

Given the above information plus the following additional information:

Molecular Weight of Biphenyl: $154.20^{13}$

Implied Benzene Concentration in Liquid (assumed all in Benzene-Surfynol ${ }^{\mathrm{TM}} 420$ phase): $128 \mathrm{mg} / \mathrm{kg}$

Measured Biphenyl Concentration in Liquid (Irradiated to $30 \mathrm{Mrad}$ ): $1903 \mathrm{mg} / \mathrm{L}$

The total number of moles of benzene calculated as above is

Moles Benzene $=(128)^{*}(36 / 1000) / 1000 / 78.11=0.0000590$

The total number of moles of biphenyl is calculated by:

Moles $=$ Concentration $($ mass/volume $) *$ Liquid Volume $/$ Molecular Weight with appropriate unitary conversions.

Moles Biphenyl $=(1,903) *(30 / 1000) / 1000 / 154.20=0.000370$

Using Equation (1) to calculate the vapor phase benzene concentration gives

Vapor Phase Benzene Concentration $=(403) *(0.0000590) /(0.0000590+0.000370)=55.4 \mathrm{mg} / \mathrm{L}$ 
J. L Barnes, 704-56H

M. J. Barnes, 773-A

T. E. Britt, 703-H

J. T. Carter, 704-56H

G. L. Cauthen, 241-119H

W. C. Clark, $704-56 \mathrm{H}$

C. L. Crawford, 773-41A

D. E. Doughty, 704-56H

L. O. Dworjanyn, 779-2A

H. H. Elder, 704-S

S. D. Fink, 773-A

J. R. Fowler, 704-Z

J. C. Griffin, 773-A

M. J. Hitchler, 730-2B

E. W. Holtzscheiter, 773-A

M. L. Hyder, 773-A

R. A. Jacobs, 704-T

M. T. Keefer, $242-153 \mathrm{H}$

L. F. Landon, 704-T

B. L. Lewis, 703-H

T. J. Lex, 719-4A

P. E. Lowe, 773-41A

D. J. McCabe, $773-43 \mathrm{~A}$

M. S. Miller, 704-56H

J. P. Morin, 719-4A

C. A. Nash, 773-42A

L. M. Nelson, 773-43A

L. M. Papouchado, 773-A

R. A. Peterson, 773-A

S. F. Piccolo, $704-56 \mathrm{H}$

M. R. Poirier, 679-T

C. T. Randall, 704-T

P. L. Rutland, 242-152H

R. M. Satterfield, 719-4A

R. F. Swingle, 773-A

W. L. Tamosaitis, 773-A

G. A. Taylor, 703-H

W. B. Van Pelt, $772-42 A$

D. D. Walker, 773-A

A. W. Wiggins, $241-84 \mathrm{H}$

A. L. Wooten, 732-B

G. T. Wright, 773-A

TIM, 703-43A

LWP Files, c/o A. Patterson, 773-A

ITP Files, c/o A. Lemay, 241-121H 